Florida International University FIU Digital Commons

3-30-2011

\title{
Transformations of a Coffee Landscape in Southern Mexico: A Case Study of Emigration and Conservation in the Sierra Norte, Oaxaca
}

Emily B. Hite

Florida International University, hite.emily@gmail.com

DOI: $10.25148 /$ etd.FI1 1051002

Follow this and additional works at: https://digitalcommons.fiu.edu/etd

\section{Recommended Citation}

Hite, Emily B., "Transformations of a Coffee Landscape in Southern Mexico: A Case Study of Emigration and Conservation in the Sierra Norte, Oaxaca" (2011). FIU Electronic Theses and Dissertations. 398.

https://digitalcommons.fiu.edu/etd/398 


\title{
FLORIDA INTERNATIONAL UNIVERSITY
}

Miami, Florida

TRANSFORMATIONS OF A COFFEE LANDSCAPE IN SOUTHERN MEXICO:

A CASE STUDY OF EMIGRATION AND CONSERVATION

IN THE SIERRA NORTE, OAXACA

\author{
A thesis submitted in partial fulfillment of the \\ requirements for the degree of \\ MASTER OF SCIENCE \\ in \\ ENVIRONMENTAL STUDIES \\ by \\ Emily Hite \\ 2011
}


To: Dean Kenneth Furton

College of Arts and Sciences

This thesis, written by Emily Hite, and entitled Transformations of a Coffee Landscape in Southern Mexico: A Case Study of Emigration and Conservation in the Sierra Norte, Oaxaca, having been approved in respect to style and intellectual content, is referred to you for judgment.

We have read this thesis and recommend that it be approved.

\begin{tabular}{rr}
\hline Elvira Duran \\
\hline Suzanne Koptur
\end{tabular}

Suzanne Koptur

David Bray, Major Professor

Date of Defense: March 30, 2011

The thesis of Emily Hite is approved.

\begin{tabular}{r}
$\begin{array}{r}\text { Dean Kenneth Furton } \\
\text { College of Arts and Sciences }\end{array}$ \\
\hline Interim Dean Kevin O'Shea \\
University Graduate School
\end{tabular}

Florida International University, 2011 


\section{ACKNOWLEDGMENTS}

I would like to acknowledge the following individuals for their invaluable assistance, guidance, knowledge, and encouragement during my time completing this thesis. I would like to thank my committee members, Dr. David Bray, Dr. Elvira Duran and Dr. Suzanne Koptur. Dr. Bray has played a critical role in developing this thesis project and has greatly contributed to my professional development through his insightful suggestions and advice. Both Dr. Bray and Dr. Duran gave me a great opportunity to travel throughout Oaxaca and learn about community conservation initiatives through the two-week field course they operated last summer. Dr. Duran and Dr. Koptur both provided me with the needed botanical knowledge to collect and analyze my ecological data, for which I am very appreciative. Advice and guidance from this committee has helped me to better understand the relationships between social and ecological sciences.

I would like to especially thank Armando Rincon Rios at UNAM for identifying plants for me. It is because of the hospitality and generosity of the community of Santa Cruz Tepetotutla that I was able to complete this project and I thank everyone for making it a memorable experience. The extensive knowledge from Pedro and Raymundo on the history and process of community conservation and coffee activities were invaluable. I also want to thank Lindsey Nieratka for her unfaltering assistance. I am grateful to the Tinker Foundation and FIU for providing me with financial assistance to complete this project as well.

I would not be where I am today without the continued love, support, encouragement and understanding from my family, for which there are no words to fully express my gratitude. 


\title{
ABSTRACT OF THE THESIS \\ TRANSFORMATIONS OF A COFFEE LANDSCAPE IN SOUTHERN MEXICO: A CASE STUDY OF EMIGRATION AND CONSERVATION
}

\author{
IN THE SIERRA NORTE, OAXACA
}

by

Emily Hite

Florida International University, 2011

Miami, Florida

Professor David Bray, Major Professor

This thesis investigates the interactions of coupled human and natural systems within a coffee landscape in Santa Cruz Tepetotutla, Oaxaca, Mexico. The community has zoned its territory into a large Indigenous Community Conserved Area (ICCA), an agricultural area, and an urban area. The coffee component of the agricultural area has undergone significant changes resulting from various responses to the coffee market. I conducted 59 household interviews and 49 vegetation transects to determine how such responses have impacted biodiversity and vegetation cover in this coffee landscape and what implications that has for the larger community landscape. Six pathways of vegetative change in the coffee landscape were identified, which suggests that it may now be more structurally and biologically diverse than at any time in the last fifty years. Given large-scale abandonment of coffee and an increased interest in ICCAs in Mexico, this research has implications for conservation in Mexico and internationally. 
TABLE OF CONTENTS

CHAPTER

PAGE

I.

INTRODUCTION 1

OBJECTIVES

COUPLED HUMAN AND NATURAL SYSTEMS 6

COFFEE

CULTIVATION METHODS 9

COFFEE PLOT BIODIVERSITY 13

NATIONAL AND INTERNATIONAL MARKET 15

COFFEE MARKET RESPONSES 18

EMIGRATION AND REMITTANCES 18

LAND-USE SHIFTS AND SECONDARY SUCCESSION 20

ORGANIZATION AND ORGANIC CERTIFICATION 21

STRUCTURE OF THESIS $\quad 25$

II. STUDY SITE AND METHODS 26

STUDY SITE: THE SIERRA NORTE $\quad 26$

STUDY SITE: SANTA CRUZ TEPETOTUTLA 30 COMMUNITY CONSERVATION 32

AGRICULTURAL AND FORESTRY MANAGEMENT 34

RESEARCH METHODS 38

ECOLOGICAL METHODS 38

SOCIAL METHODS 41

$\begin{array}{lll}\text { III. } & \text { RESULTS AND ANALYSIS }\end{array}$

ECOLOGICAL RESULTS AND ANALYSIS 43

SOCIAL RESULTS AND ANALYSIS $\quad 55$

$\begin{array}{lll}\text { IV. DISCUSSION AND CONCLUSION } & 61\end{array}$

$\begin{array}{ll}\text { LIST OF REFERENCES } & 72\end{array}$

$\begin{array}{ll}\text { APPENDIX } & 79\end{array}$ 


\section{LIST OF TABLES}

TABLE

PAGE

2.1 Vegetational Characteristics of Santa Cruz Tepetotutla

3.1 Distributions of Plot Types and Transects

3.2 Scientific and Common Names of Plants

3.3 Percent of Shade Cover per Plot Type

3.4 Basal Areas per Plot Type $\quad 54$

3.5 Current and Previous Land-use History 57

3.6 Plot Types Described by Community Members 58

3.7 Coffee Information from Surveyed Households 59 


\section{LIST OF FIGURES}

FIGURE

PAGE

$\begin{array}{lll}1.1 & \text { Coffee Cultivation Methods in Mexico } & 10\end{array}$

1.2 International Price for Coffee, January 1980-2010 17

1.3 Mexico’s Coffee Production, 1980-2009 17

$2.1 \quad$ Map of the Sierra Norte Vegetation Zones 28

2.2 Map of Sierra Norte, Including the Chinantla Region 29

2.3 Photograph of Santa Cruz Tepetotutla 30

2.4 Photographs of Santa Cruz Tepetotutla’s Agricultural Zone 36

3.1 Map of Transect and Area Locations 45

3.2 Shannon Diversity per Plot Type 51

3.3 Simpson Diversity per Plot Type 51 


\section{CHAPTER I.}

\section{INTRODUCTION}

This thesis investigates the social and ecological aspects of land-use changes in a coffee landscape in a community that has dedicated 76 percent of its lands as an Indigenous Community Conserved Area (ICCA) certified by the Mexican National Protected Natural Areas Commission (CONANP). Research was conducted in Santa Cruz Tepetotutla in the Chinantla Alta region of the Sierra Norte Mountains of Oaxaca, Mexico. The remaining 24 percent of the community's land has been divided into a 57 hectare (ha) urban zone and a 2395 ha agricultural zone. The division is a result of a land-use zoning exercise (ordenamiento territorial comunitario) carried out in 2000 and approved by the general assembly in 2003 (ERA A.C., 2000). The three zones are distinctly separated in terms of land-use regulations and management, but the natural interchanging flow of resources between them are inseperable.

The agricultural area has two components, an area of corn cultivation with significant patches of secondary succession and mature forest fragments, and an area of coffee cultivation, which has undergone significant changes resulting from emigration, abandonment and other land-use changes. Economic influences and intentional conservation efforts have been cited for the land-use decisions to emigrate and to abandon and/or shift cultivation practices, although such reasons have been little studied, particularly for coffee. Therefore, the goal of this project is to examine the links between the patterns of land-use, vegetation cover and household decision making in a coffee landscape as expressions of the interactions of a coupled human and natural system (Liu et al., 2007). 
The land tenure regime in Mexico was substantially changed beginning in the 1920's because of the Mexican Revolution (1911-1918), which led to a redistribution of land rights in the two similar agrarian units of comunidades (recognizing earlier indigenous claims to land) and ejidos (distributions to landless peasants), creating a unified basis for agrarian governance throughout the country (Bray et al., 2006). Approximately $52 \%$ of the terrestrial area of Mexico is now considered to be under community control (Bray et al., 2005), with social and natural capital being the two strongest factors influencing agrarian governance and institutions (Bray et al., 2006). Santa Cruz Tepetotutla has formed its own ICCA, and has joined with six other Chinantec communities with ICCA's in the region to create a larger scaled conservation organization known as CORENCHI, Comite de Recursos Naturales de la Chinantla, the Natural Resource Committee of the Chinantla. Together, their ICCA's protect an estimated 27,000 hectares of mature forest in the Chinantla Region of the Sierra Norte. Agricultural production throughout the Sierra Norte traditionally focused on milpa. Indigenous communities in the region utilize a combination of the farmer's knowledge of land-use history and production yields over time, in conjunction with their botanical knowledge, to choose the best management options for their fields (Van der Wal, 1999). In the 1950 's, coffee production was added to the agricultural matrix in higher elevation communities where ample rainfall and high year round temperatures provide for quality coffee production (Moguel and Toledo, 1999). The montane cloud forests and rain forests of Oaxaca, Veracruz and Chiapas have consistently produced approximately $80 \%$ of Mexico's coffee (Pérez-Grovas, 2001). 
Over $90 \%$ of production occurs in indigenous communities with smallholder, traditional farms that are less than 5 hectares in size (Santoyo et al., 1995). Their production methods were influenced and altered by government subsidy programs linked to the Instituto Mexicano del Café (INMECAFE), the Mexican National Coffee Institute, which encouraged conversion to coffee monocultures. In many cases, communities became solely dependent on coffee as a cash crop and heavily relied on the support from such programs. The communities dependent upon subsidies faced increased rates of emigration and substantial abandonment of coffee production with the rupture of the International Coffee Agreement in 1998 and with the dissolution of INMECAFE resulting from neoliberal reforms in the late 1980's (Lewis and Runsten, 2005).

The coffee crisis impacted the social and natural capital of many communities and resulted in a mosaic landscape of annual agriculture, shade tree coffee plantations and secondary forests, and in the case of Santa Cruz Tepetotutla, in a matrix of intact, managed, and non-managed cloud forests, pine-oak forests and montane tropical forests. The interchanging vegetation cover among varying plot types creates a dynamic relationship within the agricultural zone and with its bordering forested lands, which could have considerable influences on the larger landscape. Studies have shown that such "high-quality" agricultural matrices promote animal dispersal among forest fragments, sustain metapopulation dynamics and conserve biodiversity (Philpott et al., 2008).

Research has concluded that agricultural systems "make essential contributions towards conservation," with particular attention paid to coffee agroecosystems (Philpott et al., 2008). However, plant diversity, their floristic structure, and spatial and temporal variation within coffee agroforestry systems have been little studied throughout the world 
(see Bandeira et al., 2005). Additionally, the transformation occurring between and among these plots, specifically the relationship between changes in the coffee landscape and overall biodiversity and landscape change, have been little studied in Mexico or elsewhere (Tscharntke et al., 2008). The integrated ecological and sociological research, within the context of a community that has declared large areas as an ICCA, may reveal new and complex patterns only previously studied separately (Liu et al., 2007).

Mexico's position among top coffee exporters, its abundant biodiversity, and success in community conservation initiatives, make it an ideal place to conduct this study. Santa Cruz Tepetotutla was chosen as a study site because it is the site of a longterm research project by my advisor, its history of conservation and land-use decisions, its dependence on coffee for income, and the community's reportedly high rates of emigration and abandonment in response to the coffee crisis. The community is also representative of many other indigenous coffee producing communities in Mexico. The subject of this research was discussed with community leaders and this topic was suggested as a subject of community interest (Bray pers. comm). 


\section{OBJECTIVES}

This research project addresses how the decision to emigrate away from the community and shift coffee production methods has impacted the transformation of the coffee landscape and its associated plant biodiversity. Households had to decide how to diversify their income portfolios once their cash crop became unreliable, so farming households made numerous land-use decisions concerning their plots, creating various pathways of change throughout the coffee component of the agricultural landscape. The review of biodiversity in coffee plots (below) and forests managed at various intensities (Rouvinen and Kuuluvainen, 2005) leads me to expect that the least managed coffee fields (abandoned) will have richer biodiversity, more vegetational cover and higher structural complexity than plots that are more heavily managed at this study site. The following questions will be addressed:

1. What are the changing pathways of vegetation cover experienced by coffee farms in the coffee landscape as a result of emigration, changes in agricultural policy and the instability of coffee prices?

2. What is the species richness of plants in the six identified pathways of change in the coffee landscape and what implications does that have for biodiversity and conservation in the larger landscape? 


\section{COUPLED HUMAN AND NATURAL SYSTEMS}

Better understanding the nature of coupled human and natural systems may provide governments, researchers and communities with the capability to protect biodiversity and watersheds, manage forests sustainably and alleviate poverty, simultaneously. Vegetation studies have taken place in the community and region (Van der Wal, 1999; Martin, 1996; Meave del Castillo, 1998), but not in the coffee landscape. Research on jaguars and their prey in the region has combined both sociological and ecological investigations in the community (Figel, 2008). My study will contribute to our knowledge concerning the ecological value of the agricultural zone, which is in close proximity to a large conserved area.

Liu (2007) defines coupled human and natural systems as integrated systems in which people interact with natural components. According to Liu (2007), variables that

link components of human and natural systems are not identifiable through independent studies of ecology or sociology alone. Components are not identifiable because the systems are reciprocal and create complex feedback loops that vary depending upon location and systems involved. Most coupled relations are nonlinear and therefore have various transitional and alternate states. The outcome of human actions cannot be foreseen without a complete understanding of its coupled interactions within nature, which may be subject to time lags and legacy effects, impacting society's ability to react. Finally, not only does the resiliency of coupled systems greatly vary, but so does their heterogeneity in space, time and organization.

Although the communities in the Chinantla Alta are now known for their ICCAs, the impact of other socio-economic processes on landscape conservation within and 
beyond the ICCAs are not well understood (Robson, 2009). Once the associations between large-scale economic forces, such as commodity prices and labor migration, local communities, and landscape change are recognized, local and international communities will benefit through a greater understanding of sustainable resource management techniques, providing the opportunity to create or improve community management institutions. Santa Cruz Tepetotutla and other communities may be able to directly benefit through new conservation initiatives and programs, as their contribution to global biodiversity and ecosystem conservation is acknowledged.

\section{COFFEE}

The impacts of the international coffee market on the community landscape have undergone three main transitional periods. The 'Introductory Period' began in the 1950's and continued through the 1960's, when coffee was first brought into communities and production began on a small-scale. Landscapes began to transform from either forest or corn to coffee in areas immediately surrounding the village of Santa Cruz Tepetotutla. The second time period of 'Expansion and Stabilization' was throughout the 1970's and 1980's, when coffee prices were relatively high and stable, in large part because of national subsidies and regulation by an international quota system managed by the International Coffee Organization (ICO). During this second period, coffee production methods intensified, more land conversion into coffee occurred, and production and output increased. Stability in the market during that time resulted in a stable coffee landscape in Santa Cruz Tepetotutla and elsewhere in Mexico. In 1989, the third period of 'Destabilization and Recovery' began when the quota system managed by the ICO and 
subsidies from INMECAFE destabilized communities with price uncertainties and drove subsequent changes in the landscape. Communities have coped with this "International Coffee Crisis" in various ways, which has impacted and transformed the landscape in this coupled system.

Responses to the market crash include 'technification' and diversification of production, which also may correspond with intensification or certified organic production, and organization of small farmer cooperative confederations, such as the Coordinadora Estatal de Productores de Café de Oaxaca (CEPCO) (CEPCO, 2011), of which a cooperative named La Luz de la Chinantla in Santa Cruz Tepetotutla was a member. Abandonment and emigration of people from coffee growing regions to other parts of Mexico and into the United States have also been responses to the market in some communities, with abandonment, emigration and organization having each occurred in the study community. Each of these responses has significant implications for the transformation of the landscape on local and regional scales, and will therefore be examined more closely in the following sections along with their associated impacts.

First, it is important to consider the varying types of cultivation and management methods utilized within coffee plots, because production intensity has implications for the ecological integrity of a coffee landscape and for the landscape as a whole. Next, the importance of a coffee agroecosystem's biological diversity will be described, as well as its ability to contribute to regional biodiversity conservation. Third, the coffee market is examined with regards to the impact its instability has had in producing regions. Emigration, one of the many responses to the fluctuating market, and its associated remittances will be addressed next because it can influence economic stability of a 
community, as well as its natural capital. The fifth section will discuss land-use shifts within a coffee landscape may transform landscapes on local and regional levels through secondary succession. Finally, the ability of farmers to continue producing coffee through community organization and organic certification is discussed, since it promotes environmentally friendly practices that may allow for the continuation of a region's ecological functions.

\section{CULTIVATION METHODS}

Coffee plants may produce beans for 20-40 years, after an initial 3-year growing period. Bandeira et al. (2005) have named three stages of a coffee life cycle: establishment, development and decline. Typically, a mature or secondary forest or abandoned corn plot is cleared of small shrubs or plants that are not utilized by the household, and coffee is planted. Inga spp. trees are widely recognized and used as a shade tree and nourished to maturity, and subsistence crops like tepejilote (Chamaedorea tepejilote) or yucca (Yucca guatemalensis) are allowed to remain in the plot. Eventually the plants no longer produce profitable amounts of coffee and the plot will be used only for fruit or wood collection, left fallow for several years, abandoned completely, replanted with coffee, or converted into an annual agricultural plot.

Tscharntke et al. (2008) recognized that "species experience their surroundings at spatial scales beyond the plot level, and spillover between natural and managed ecosystems is common" and state that studying human-dominated landscapes is essential to the understanding of the functional diversity of tropical ecosystems. Moguel and Toledo (1999) found that coffee cultivation affects both ecological and biological natural 
ecosystem processes, including levels of biological diversity, carbon dioxide cycling, hydrology, soil quality and forest cover. Many studies have shown that traditional polycultures are able to sequester about $1 / 3$ of the amount of carbon that a mature forest is capable of capturing, because of its diversity and biomass (Perfecto et al., 2007).

Forests filter water, recharge groundwater, reduce flooding, provide aquatic habitats and protect the overall ecosystem function of the region (Calo and Wise, 2005).

Moguel and Toledo (1999) have described five types of coffee cultivation in Mexico, which are defined by their management levels and vegetational and structural complexity. They are traditional rustic, traditional polyculture, commercial polyculture, shaded monoculture and unshaded monoculture (Moguel and Toledo, 1999; Figure 1.1).

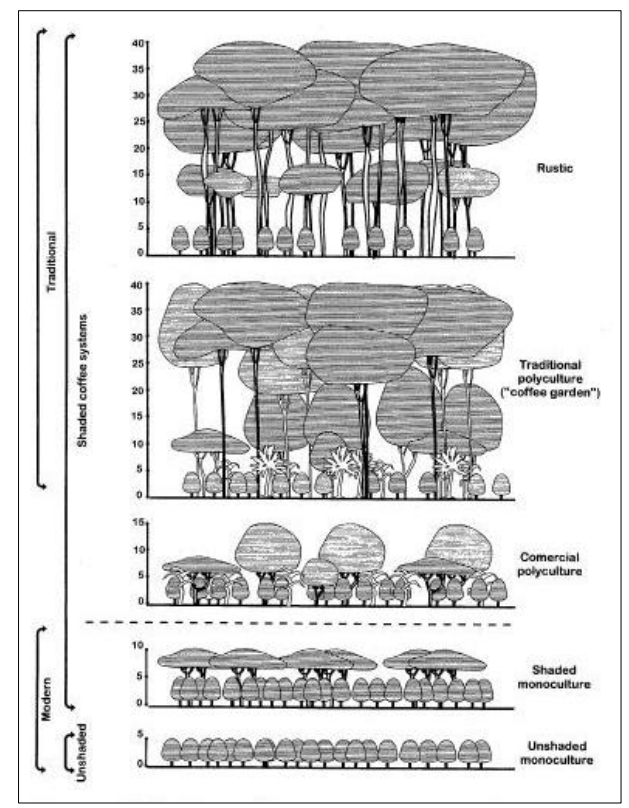

Figure 1.1 Coffee Cultivation Methods in Mexico Source: Moguel and Toledo, 1999. 
Traditional rustic and traditional polycultures do not use agrochemicals or synthetic input, require minimal management and retain significant levels of biodiversity (Moguel and Toledo, 1999). Toledo et al. (1995) found that indigenous groups are able to utilize 1330 plant species and 3173 forest products from these coffee cultivation systems for subsistence, food, medicine or local markets. The traditional methods used by indigenous peoples have resulted in approximately $2 / 3$ of the production of coffee in Mexico coming from traditional shaded polycultures (Moguel and Toledo, 1999). Modern cultivation methods of commercial polycultures, shaded, and non-shaded monocultures, each utilize pesticides, fertilizers and insecticides to enable and promote growth and yield. They require greater management and monitoring and are focused on larger market production. Each of these requires that the entire forest be cleared, usually through slash and burn methods, then the target plants are sown. The process of clearing out plots, for these modern methods, negatively impacts plot biodiversity.

Santa Cruz Tepetotutla began coffee production under the shade of the natural forest and in gardens next to their homes beginning with coffee's introduction in 1955, which would be categorized by Moguel and Toledo (1999) as a traditional rustic or traditional polyculture plot. However, some farmers converted their non-shaded corn plots into non-shaded coffee plots during this same introductory time period. As a result of the global increase in demand for coffee, stability in the market, and encouragement from INMECAFE in the form of subsidies, many annual agriculture, sugar plots and forested lands were converted into coffee plots during the second coffee period 1970's and 1980's when the market was stable. Converting corn plots meant that the new coffee system would be an unshaded monoculture, since it would have been slash and burned 
and cleared of any mature shade trees. The current coffee landscape in Santa Cruz Tepetotutla reflects this expansion, as many coffee plots have minimal shade, although farmers stated that the high degree of cloud cover over much of the year, reduces their need for shade. A reported 19\% of community members changed mature forests into cleared monoculture plots, and 24\% replaced their corn monoculture with coffee in Santa Cruz Tepetotutla, which will be discussed more in the analysis section.

Rice (1997) describes the landscape transformations in a coffee region of Chiapas, Mexico where there are two initial transformational paths to coffee production. In a "direct" path, similar to the above described traditional cultivation systems, coffee is planted among native forests that retain their canopy and structure, although it produces low yield. Landscape modification as a whole is minimal in this method, with the vertical structure of the forest left intact. Some of the farmers in Santa Cruz Tepetotutla began their coffee production in this method, although some cultivation methods would be categorized as the second transformation that Rice (1997) describes as an "indirect" path. The "indirect" path is one described as capitalizing on an acahual, or fallow cornfield, by planting coffee instead of returning it to milpa production. The land-use change in this path would tend to be more intensive, as only certain trees like nitrogen fixing Inga spp. are permitted to grow. However, these are not exactly comparable to the traditional vs. modern cultivation methods since the plant density in the direct system is higher than in the indirect system (Rice, 1997), with biodiversity decreasing as crop density increases. Indigenous communities in the Chinantla Alta had traditionally produced coffee through the rustic and coffee garden methods, with low-density plots that produced low yields, similar to direct system, or traditional polycultures. Farmers in Santa Cruz 
Tepetotutla, along with other indigenous communities, also converted their cornfields, forests and other plots into a more intense coffee cultivation system through support from INMECAFE. Overall, despite land-use conversions among farmers throughout Mexico during this second period of coffee production, only 17\% of Mexico's coffee production is cultivated in monocultures, the lowest amount reported out of all the Latin American countries (Rice and McLean, 1999). This report is interesting because it was reported in Santa Cruz Tepetotutla that coffee production was mostly occurring in monoculture, minimally shaded plots as a result of conversion from corn into coffee production.

\section{COFFEE PLOT BIODIVERSITY}

Not only is Mexico one of the top five most megadiverse countries in the world (Llorente-Bousquets and Ocegueda, 2008), Oaxaca has the most biodiversity of any state (Garcia-Mendoza et al., 2004) with 4,085 species of vascular plants and 1,322 species of vertebrates (Llorente-Bousquets and Ocegueda, 2008). During a study that focused on biodiversity hotspots throughout Mexico, it was concluded that 14 of the country's major coffee producing regions overlap with areas of high species endemism and biodiversity (CONABIO, 2011).

Quantitative studies by Moguel and Toledo (1999) conclude that indigenous traditional coffee agroforests are "important repositories of biological diversity," where vegetation and architectural complexity of the forest reach their highest "useful diversity." Moguel and Toledo (1999) concluded that traditional polycultures can act as refuges for many species that need to escape highly disturbed lands and can also protect regional ecological processes because they allow other plants and trees to grow within 
the system simultaneously. Traditional production of coffee, in diverse shade matrices of Mexico, has contributed to the region's ecological stability (Perfecto et al., 2007).

In 1932, Ludlow Griscom pioneered vertebrate research in coffee plantations by publishing a study, which stated that the population structures of bird diversity and density did not vary significantly between traditional coffee plantations and "virgin forests" (Bray, 1999). Lewis and Runsten (2005) state that traditional coffee plantations support $60-70 \%$ of the species that are found within mature forests, which includes more than 150 bird species (Rice and McLean, 1999). Additionally, a large number of endemic species and richness of butterflies coincides with locations of traditional coffee plantations (Llorente-Bousquets et al., 1996). Ant and pollinator biodiversity, as well as natural pest control, are also thought to be very high in traditional systems (Perfecto et al., 2007).

Traditional coffee systems have been shown to support between 90 and 120 species of plants in studies in Mexico (Rendón and Turrubiarte, 1985; Molino, 1986). Moguel and Toledo (1999) reviewed plant diversity studies within different coffee systems of Mexico and found that traditionally managed plots can maintain between 13 and 58 tree species within a diverse mixture of canopy, medium sized and understory vegetation.

Despite the high amounts of biodiversity in traditional coffee plantations, an individual coffee plot may not be able to directly affect the biodiversity of an entire landscape (Bandeira et al., 2005). However, research in a region nearby the study site, which likely generalizes the characteristics of many fragmented systems, concluded "it is the sum of the heterogeneous patches in the fragmented landscape which makes this 
agroforestry system valuable for wild tree diversity conservation" (Bandeira et al., 2005). Moguel and Toledo (1999) state that the architectural, vegetational and structural complexity of Mexico's coffee systems can have impacts at the microenvironmental and regional scale. Abundance of shade is an indicator of landscape equilibrium and absence of shade trees results in a "less stable physical environment" (Moguel and Toledo, 1999).

\section{NATIONAL AND INTERNATIONAL MARKET}

Mexico's traditional agricultural production methods allowed farmers to produce a variety of goods for the market and for household subsistence. The dual production strategy allowed them to maximize production options and minimize financial risks (Toledo et al., 2003). It insured farmers the "maximum use of limited land holdings" in the face of market uncertainties, natural disasters, and societal issues (Rice and Ward, 1996). Production methods were altered as the global coffee market increased substantially through international trade agreements and government subsidy programs.

The International Coffee Organization (ICO), established in 1962, was formed through the ratification of the International Coffee Agreements (ICA), signed by producing and consuming countries (Calo and Wise, 2005). The ICO's mission is "to strengthen the global coffee sector and promote its sustainable expansion in a marketbased environment for the betterment of all participants in the coffee sector." In the 1960 's to 1980 's, the ICO regulated the coffee market utilizing a quota system. It helped balance the market so that no single country held a monopoly, and kept countries from flooding the market. 
The Mexican government established the Instituto Mexicano de Café (INMECAFE), the Mexican Coffee Institute, in 1959 to assist in its expansion of coffee production. Coffee was produced on 356,000 ha in 1970 , but increased to 762,000 ha in 1992 (Calo and Wise, 2005) and has remained around 800,000 ha since (Moguel and Toledo, 1999). The Mexican Coffee Institute became responsible for administering the ICA quotas for Mexico and beginning in 1973, was fully in charge of exporting the country's coffee (Topik et al., 2010). They provided coffee plants, financial and technical assistance, transportation, processing facilities and a guaranteed market to producers (Moguel and Toledo, 1999). This method briefly increased output, but drastically and negatively affected biodiversity and landscapes (Nestel, 1995; Rice, 1997).

The International Coffee Organization's quota system collapsed in 1989, causing the "International Coffee Crisis" (Lewis and Runsten, 2005). Coffee prices dropped from $\$ 120$ USD per quintal to $\$ 55-\$ 60$ USD per quintal (1qq = 100lbs.). Then, between 1989 and 1993, Mexico phased out INMECAFE, ending all subsidies and assistance. Coffee production dropped $33 \%$ in response, from 7.16 million quintals to 4.77 million quintals (Celis, 1993). There has not been stability or recovery from this market disturbance, which can be seen in the following figure that shows the international price for coffee between 1980 and 2010 (Figure 1.2). Brief increases in the price in the mid to late 1990's can be attributed to adverse weather conditions in Brazil (Rice, 1997). 


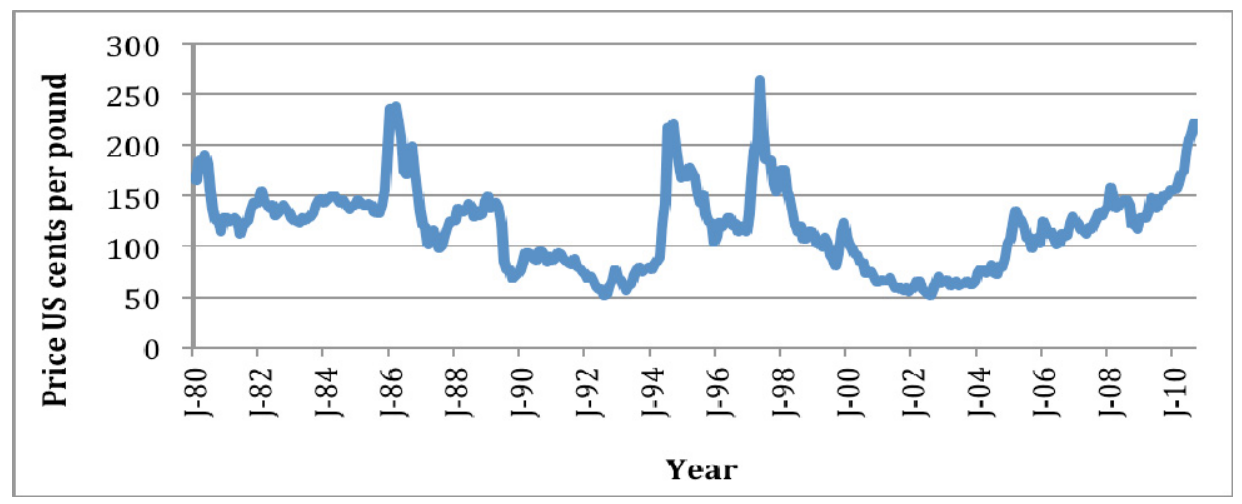

Figure 1.2 International Price for Coffee, January 1980-2010 Source: Mongabay, 2011

The Food and Agricultural Organization's 2003 report on agricultural commodities includes projections for the global coffee industry through 2010 (FAO, 2003). Their models estimate that coffee production will decrease from its $1.9 \%$ annual growth rate during the 1988-1998 growing years, to $0.5 \%$ between the 1998 and 2010time period. Latin American countries are predicted to remain the largest producing regions, however the region's overall growth rate will drop from $1.7 \%$ to $0.4 \%$ in the projection period. Mexico's coffee production is seen in the following figure.

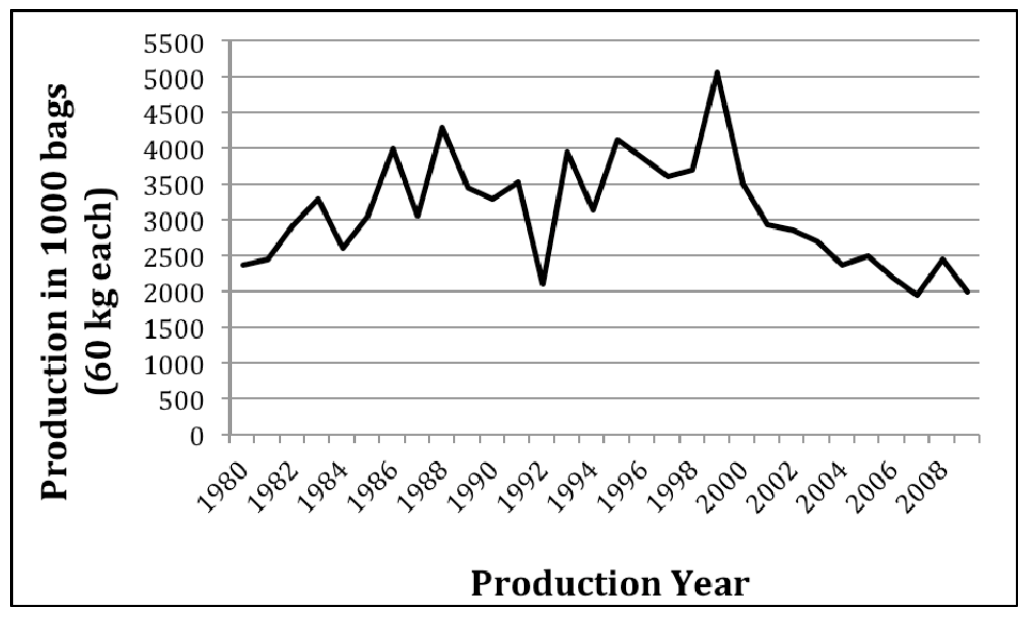

Figure 1.3 Mexico's Coffee Production, 1980-2009

Source: FAO, 2010 


\section{COFFEE MARKET RESPONSES}

Responses to the market fluctuations have varied greatly. Wealthy private farmers invested in the technification of their coffee plots, utilizing fertilizers and converting into monocultures (Perfecto and Armbrecht, 2003). Small holders who once relied on INMECAFE, reverted back to the system of middle men, known as coyotes, who transported coffee and sold it to larger corporations (Jaffee, 2007). Coyotes were marginalized during the period of INMECAFE's presence, but became valuable assets after it was phased out. Some communities adapted by planting coffee at lower elevations, at 1000 meters or less, in order to produce beans earlier in the season (Mutersbaugh, 1994) even though coffee grown at lower elevations is not the same quality and generally receive lower prices. A comprehensive review of responses to the coffee market is discussed in a report by Tucker et al. (2010). Responses to the national and international coffee market by households in Santa Cruz Tepetotutla included emigration, various land-use shifts and organization, which will each be discussed in detail below.

\section{EMIGRATION AND REMITTANCES}

Migration has been one of the responses to the fluctuating coffee market, with remittances providing an important new source of income (Lewis and Runsten, 2005). Arguments over the ability of migration and its subsequent remittances to improve economic and social conditions in communities ensue, with some asserting that benefits to the community depend on the strength of the community's organization (VanWey et al., 2005). Migration to the United States from Mexico has been occurring at least since 
the early 1900's, which has allowed migrant workers to send remittances to their families, thereby decreasing their financial risks (Lewis and Runsten, 2005).

Coffee producing communities in the southern Mexican states were historically able to resist migration because they have large tracts of productive land. However, since the coffee market crash, these communities have become the top migrating regions in the country (Lewis and Runsten, 2005). An estimated 800,000 coffee workers emigrated from Veracruz between 1995 and 2000, and approximately 1.6 million emigrated from Chiapas (Topik et al., 2010). Migration from Oaxaca increased in the 1970's, with the majority being Mixtec indigenous peoples (Lewis and Runsten, 2005). By 2000, Oaxaca represented four percent of migrants in the US, and may now be the largest sending state of new migrants from Mexico (Lewis and Runsten, 2005).

Migration in the southern Mexican states is typically a temporary response to a stressor (Tucker et al., 2010). In the indigenous communities of the Sierra Norte that utilize the system of usos y custumbres, community members are required to work in cargos and tequios. If a community member has emigrated, they will need to find a replacement to perform their tequio, pay a fee to the community to hire someone else, or pay a lump sum when they return (VanWey et al., 2004). Mutersbaugh (2002) concludes that the system of cargos and tequios discourages and limits the migration from a community, by raising the costs of leaving, such as loss of land tenure rights. Community members in Santa Cruz Tepetotutla have noted their need to return to fulfill their community obligations, and many have stated that family members have emigrated and returned on more then one occasion for varying lengths of time. 


\section{LAND-USE SHIFTS AND SECONDARY SUCCESSION}

The abandonment and shifting land-use methods in coffee fields can be the result of emigration, or a separate response to the coffee crisis, in which household members decide to shift their land-use pattern by utilizing different cultivation methods. Tucker et al. (2010) describe these decisions as "adaptations" that are a result of a conscious and deliberate adjustment to land-use activities in response to the market or other stressors, which may have long-term implications for the landscape. For example, the landscape in dry tropical forests of southern Mexico is now dominated by increasingly larger and interconnected secondary forest fragments as a result of the decision to abandon agricultural plots (Galicia et al., 2008).

It has been noted that higher rates of abandonment and land-use shifts have occurred in communities that relied on INMECAFE, because their fields required expensive inputs that farmers could no longer afford (Rice, 1997). Abandoned plots may be able to maintain biodiversity and play a critical role in tropical forest species abundance, if given appropriate recovery time and proximity to seed sources (Dent and Wright, 2009). The agricultural zone in Santa Cruz Tepetotutla has proximity to large tracts of certified protected forests and has been shifting through various forms of cultivation for approximately 20 years. It therefore might be able to maintain its high levels of biodiversity in the coffee landscape.

However, there is limited documentation on the ability of coffee fields in particular to regenerate into mature forests after abandonment, with those findings mainly focused on research in Nicaragua (Griffith, 2000), El Salvador (Hecht et al., 2002) and Puerto Rico (Weaver and Birdsey, 1986; Zimmerman et al., 1995; Rivera and 
Aide, 1998; Pascarella et al., 2000; Marcano-Vega et al., 2002; Brasch, 1987; Nir, 1988). The majority of studies have been short-term because these land-use decisions have happened only in recent decades, during the third coffee period (Pascarella et al., 2000).

Marcano-Vega (2002) suggests that abandoned shaded coffee plantations provide essential seed sources for species diversity at the landscape scale. Rivera and Aide (1998) concluded that a farm's land-use history has the ability to impact forest dynamics for long periods, an example of a legacy effect, and it will determine its pattern of regeneration. After approximately 30 years since abandonment, coffee plots in Puerto Rico were reaching similarity in composition to mature forests, with 25 or more woody species, although it has been suggested that fully abandoned lands may not reach full vegetation complexity until after 60 or more years (Marcano-Vega, 2002). Some of the abandonment of coffee plots and shifting cultivation methods in Santa Cruz Tepetotutla have been occurring for at least 20 years, and this study will contribute to calculating their regeneration time on the basis of their biodiversity and vegetational complexity.

\section{ORGANIZATION AND CERTIFICATION}

The most commonly used form of governance in the comunidades of the Sierra Norte is that of usos y custumbres (Robson, 2009). The usos y custumbres form of governance extensively utilizes a traditional hierarchical system of community authority known as the cargo system with democratic practices introduced by Mexican agrarian law. The system helps determine production and conservation decisions within the community (Mitchell, 2006). 
Although individual communities had strong governance structures and were successfully managing their resources after the Mexican Revolution, they needed assistance with marketing coffee after the international price collapse. Communities joined to form multi-tiered regional networking organizations that perform a duel function by representing community interests in the political realm at the national level (Pérez-Grovas et al., 2001). Multi-tiered organizations incorporated social, economic and ecological aspects into their coffee production (Lewis and Runsten, 2005) by utilizing strong governance structures, cooperation and information transparency between all stakeholders (Ostrom, 1990). Organization among coffee producing communities may have implications for the landscape, if they are supported and encouraged to farm with traditional methods and not have to convert their farms into annual agriculture or pasture lands.

Oaxaca led the country in its mobilization of local communities for resource reform through its indigenous environmental movement in the 1970's and early 1980's (Mitchell, 2006). The environmental movement was initially spurred by control over logging, and after 30 years of maturation of the community logging regime, more formal practices of community conservation emerged. Approximately $80 \%$ of Oaxaca's forests are now managed by about 1400 communities or ejidos (Robson, 2009). In regards to coffee production, organization among producing communities has been a collective effort that has allowed Mexico to retain its place among the top coffee exporters and become a leading exporter of organic coffee (Bray et al., 2003). 
In 1989, the National Coordinator of Coffee Organizations (CNOC) was established to assist with organizational structure in communities (Pérez-Grovas et al., 2001). The CNOC at one time represented $35 \%$ of the small coffee farmers of Mexico. They negotiate with the national government and international buyers on behalf of regional community organizations in order to bring the farmers the best prices for their coffee (Pérez-Grovas et al., 2001). A number of regional and local organizations formed so that CNOC could work more efficiently with communities. The State Coordinator of Coffee Producers of Oaxaca (CEPCO) is one regional networking organization that successfully represents 34 local community coffee producing organizations (PérezGrovas et al., 2001), which once included Santa Cruz Tepetotutla.

Networking organizations have aided smallholders in remaining in the market by promoting traditional, shade grown and organic production (CEPCO, 2011), which have become widespread in Mexico because of the low intensity production techniques already utilized by most of the farmers (Lewis and Runsten, 2005). Organic and fair trade certification provides farmers with a higher price per pound (Pérez-Grovas et al., 2001), which may dissuade them from converting their fields into pasture lands or other more intensive activities. Researchers have suggested that the need for farmers to migrate away from their communities to work is reduced when households are able to participate in fair trade and organic certification programs because of this higher income base (Murray et al., 2003), although other studies show that the benefits can be marginal (Calo and Wise, 2005; Jaffee, 2007).

There have been some problems reported that are associated with organic certification. First, each government or non-profit organization that certifies coffee has 
their own set of standards and regulations, which may instill a lack of confidence in the consumer. Second, some certifying entities require upfront investments that smallholder farms will not be able to afford, limiting who may become involved in the program. Organic markets do not support communities with credit or institutional support during the transitional phase from conventional to organic production (Calo and Wise, 2005). A third issue is that affects organic coffee is the presence of infestations, such as the American coffee leaf spot disease or a coffee berry-boring insect (Lewis and Runsten, 2005). Lewis and Runsten (2005) reported that $93 \%$ of organic farmers in Mexico have the presence of one or both of those diseases, which have been reported in Santa Cruz Tepetotutla, and must increase management to ward off their affects, by constantly clipping and maintaining coffee plants. The additional work required for organic certification may be a deterrent for smallholder farms that do not have the labor force to maintain organic plots.

Strong organization within Santa Cruz Tepetotutla, and with other communities in the Sierra Norte, allowed them to work with CEPCO to certify their coffee. However, after only a few years, disagreements about management, strict regulations and low prices ended the relationship. Leadership struggles within CEPCO added to the problems of certification, which is how the community's cooperative, La Luz del la Chinantla, was formed. La Luz de la Chinantla still assists farmers with their sales, but they no longer receive organic certification. Organic farmers in Santa Cruz Tepetotutla were receiving the same price per kilo as non-certified farmers because of the international market, which does not promote the continuation of sustainable farming practices. Difficulties with CEPCO and low certification prices likely led to more plot abandonment or shifting 
agricultural production and added to the overall impact on the community landscape. However, many community members have stated that they are interested in becoming certified again and some have continued to maintain their plots along CEPCO's organic standards.

\section{STRUCTURE OF THESIS}

Chapter II will begin by describing the study site, including its unique ecology, conservation strategies and managerial framework, and follow with a two part section on methodology. The first part describes the ecological methods, followed by a description of the sociological methods. Chapter III presents the results and analysis of both the ecological and sociological data, separated into their own sections. Chapter IV concludes the thesis by discussing the correlations between the ecological and sociological analysis, the key findings and provide implications and suggestions for local and global community forest management. 


\section{CHAPTER II.}

\section{STUDY SITE AND METHODS}

In May of 2010, I participated in a two-week field course in the Sierra Norte, with students and faculty from FIU and CIDIIR-Oaxaca. This collaborative program provided me with the opportunity to interact with numerous government and non-profit organizations working in the Sierra Norte. It was a valuable introduction to the diverse community enterprises in operation throughout the region. A description of the Sierra Norte and Chinantla Alta is presented below, followed by a detailed discussion of Santa Cruz Tepetotutla, including the community's organization, agricultural land management, forest and landscape. Research was conducted between June 4, 2010 and July 23, 2010, during which time I conducted ecological and sociological field research. The methods of research are presented after the study site descriptions.

\section{STUDY SITE: THE SIERRA NORTE}

Confusion arises around the exact territory included in the "Sierra Norte." GomezMendoza (2006) embraces the official administrative divisions of the state of Oaxaca, and includes the region of the Mixe indigenous people. However, the Mixe region is dissimilar in terms of recent land-use history and ethnicity from the part of the Sierra Norte occupied by the Sierra Zapotec and Chinantec indigenous peoples. The official Sierra Norte zone also does not include my study site, which is in the "Chinantla Alta" in the district of Tuxtepec. Nonetheless, the Chinantla Alta forms a geomorphological vegetative cover and ethnic continuum with the "Sierra Norte Zapoteca-Chinanteca," and for the purpose of this research is considered part of the Sierra Norte. 
The Sierra Norte Mountains are formed by the convergence of the eastern and western Sierra Madre mountain chains, that span $300 \mathrm{~km}$ long and are $76 \mathrm{~km}$ wide (Gómez-Mendoza et al., 2006). The region in general has a rough topography, created through a long history of geologic uplift (Arteaga and Calderón, 2008). The Sierra Norte is part of the Madrean Pine-Oak Woodland Biodiversity Hotspot (Koleff et al., 2004) and is characterized by an expansion of pine and oak forest cover (Gómez-Mendoza, et al., 2006). The pine-aok forests of the region are listed as one of the World Wildlife Fund's Global 200 eco-regions because of their high levels of biodiversity and endemism (WWF, 2005).

Between the 1950's and 1970's, the pine forests of Sierra Norte were being heavily deforested and became known for its logging, which was being done under a logging concession. The most valuable of the pine species, the Chiapas pine (Pinus chiapensis), was heavily fragmented throughout its range in the Sierra Norte. It is now considered to be a species of "special consideration" in Mexican environmental law (Castillo and Acosta, 2002). When communities gained more control of their resources in the 1980's, they began to diversify their commercial enterprises by integrating eco-tourism, water bottling, sustainable forestry and organic certification into their management schemes. The communities without commercially viable forests began trying to capitalize on conservation in the last decade (Bray, pers. comm.).

Shifting land-use patterns in the Sierra Norte have been documented by GómezMendoza et al. (2006) in their study of deforestation (Figure 2.1). In 1980, the Sierra Norte had $4.18 \%$ pine forest, $14.64 \%$ evergreen tropical forest, $11.74 \%$ montane cloud forest and $8.39 \%$ dry tropical forest. Agriculture accounted for $6.68 \%$ of the land, and 
$1.44 \%$ was pastureland. In 2000, all of these percentages decreased because of increased agricultural development; $2.5 \%$ of pine forest was recorded, $8.89 \%$ evergreen tropical forest, $10.39 \%$ montane cloud forest and $8.09 \%$ dry tropical forest. Agriculture lands increased to $8.11 \%$ and there was $1.69 \%$ pastureland. However, not every community in the Sierra Norte faced deforestation at these rates, which is illustrated by the highly forested area of montane forests in Santa Cruz Tepetotutla.

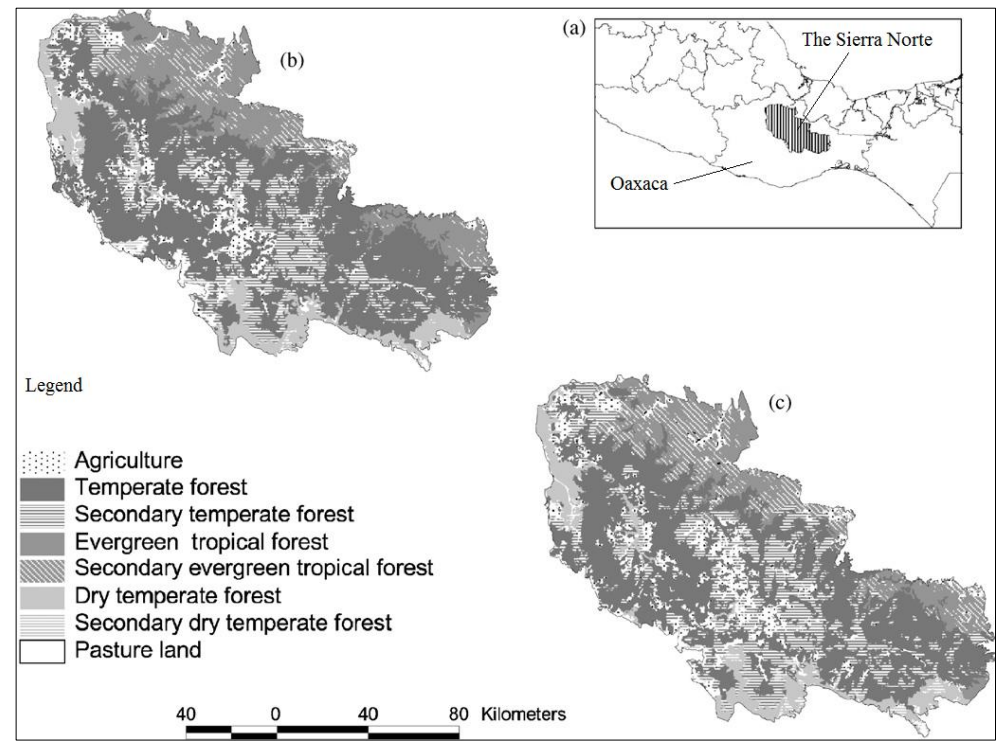

Figure 2.1 Map of the Sierra Norte Vegetation Zones Source: Modified from Gómez-Mendoza et al., 2006. a) Location of the Sierra Norte within the state of Oaxaca b) 1980 land-use cover c) 2000 land-use cover.

Gómez-Mendoza (2006) study on land-use changes also shows that there were significant increases in secondary forest growth throughout the Sierra Norte. Between 1980 and 2000 , there was a $136 \%$ increase in secondary pine forests, $79.6 \%$ in secondary pine-oak forests, $29.3 \%$ in secondary montane cloud forests, $77.8 \%$ in secondary evergreen tropical forests and $19.3 \%$ in secondary dry tropical forests. Deforestation and land-use disturbances continued during the study period, however, increased secondary 
succession forests may be a result or combination of abandonment, emigration or intentional conservation decisions. Community conservation has become more important in recent years, and now the Sierra Norte is known for its Indigenous Community Conserved Areas.

The Chinantla region of the Sierra Norte (Figure 2.2) is considered to have one of the most complex landscapes in Mexico (Álvarez, 1994). The Chinantla is located approximately between $17^{\circ} 22^{\prime}$ to $18^{\circ} 12^{\prime} \mathrm{N}$ and $95^{\circ} 43^{\prime}$ to $96^{\circ} 58^{\prime} \mathrm{W}$ (Schultes, 1941).

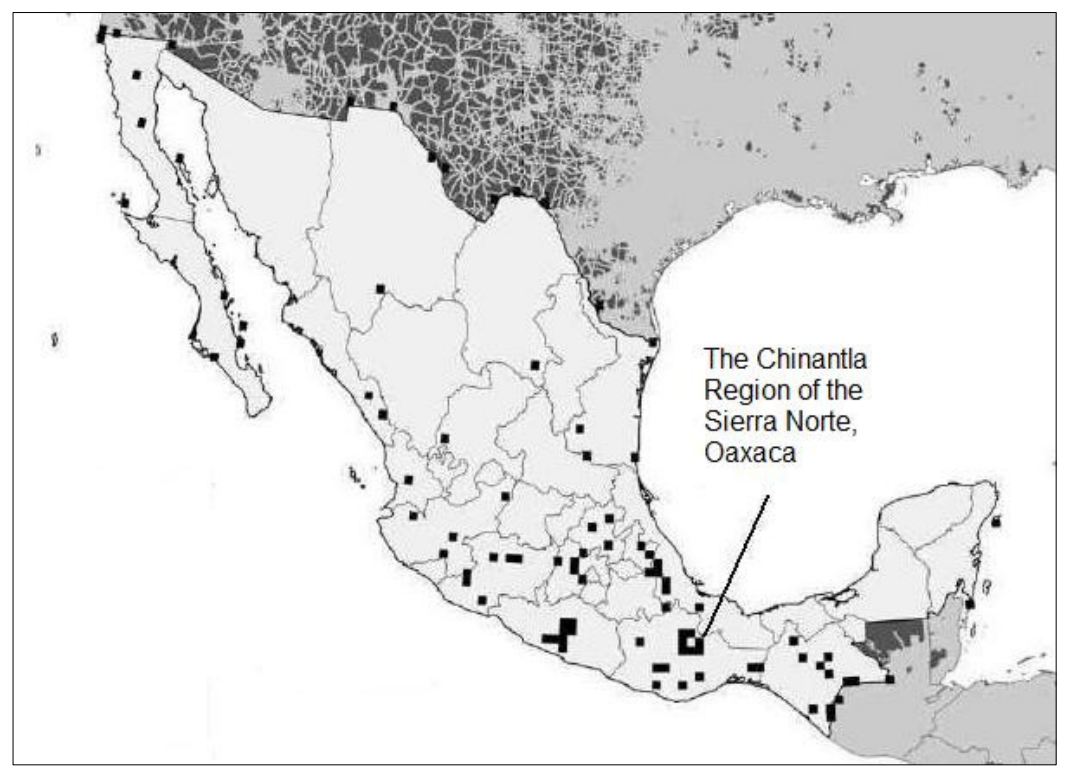

Figure 2.2 Map of Sierra Norte, Including the Chinantla Region.

Source: Modified from Brandon et al., 2005.

Elevations range from $50 \mathrm{~m}$ to $3200 \mathrm{~m}$ over a distance of less than $50 \mathrm{~km}$ (Van der Wal, 1999), creating slopes between 18 and 44 degrees (Ortíz-Pérez et al., 2004). Soil is generally classified as lithosol (Alfaro et al., 2004) and the climate is hyper-humid (Meave et al., 2006). It is one of the last places in the country to have large, undisturbed tracts of oak forests (Meave et al., 2006) and it has the third largest area of contiguous rain forest in Mexico (Aguilar, 2007). There are also evergreen conifer forest (2750m - 
$2250 \mathrm{~m})$, pine-oak forests (2000-3200m), oak and oak-pine forests (1400-2000m),

montane cloud forests (also referred to as bosque mesofilo) (1200-2600m) and tropical evergreen forests (200-1600m) (Martin, 1996).

\section{STUDY SITE: SANTA CRUZ TEPETOTUTLA}

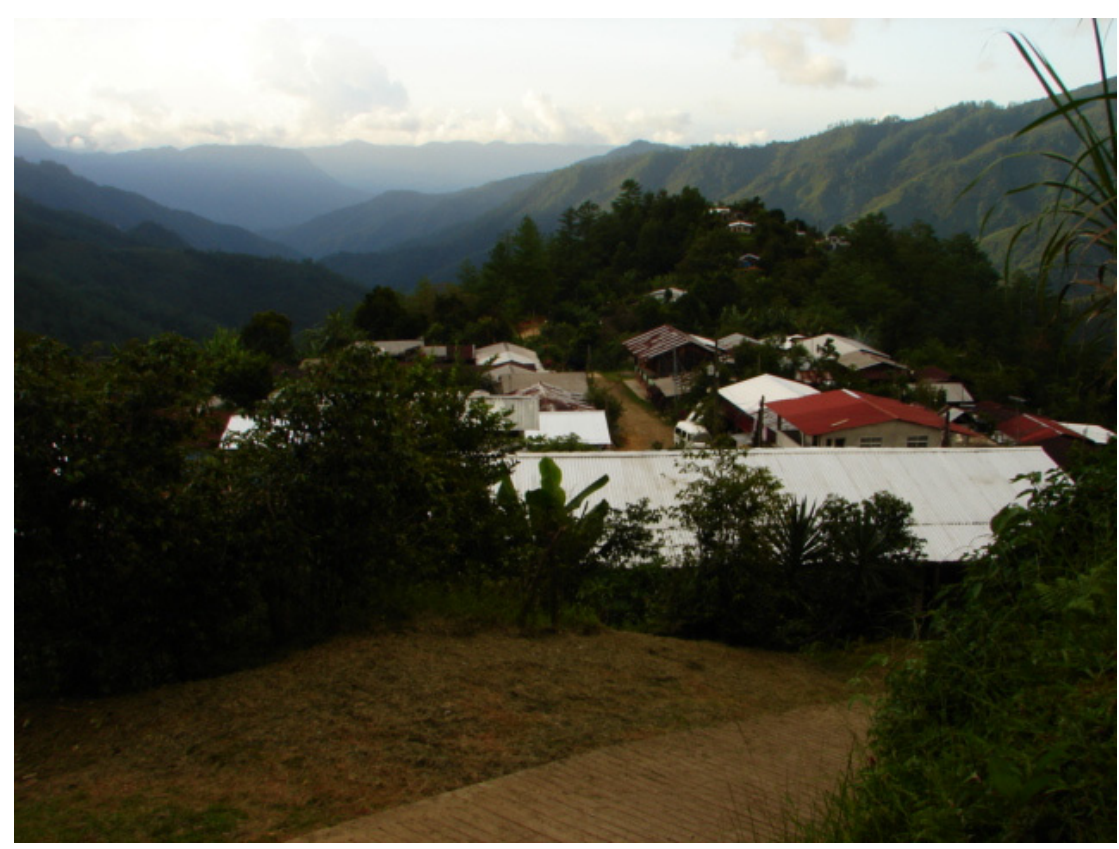

Figure 2.3 Photograph of Santa Cruz Tepetotutla $($ Emily Hite

Santa Cruz Tepetotutla occupies over 12,000 ha in the San Felipe Usila municipality of Oaxaca in the Chinantla Alta. Although there are commercially valuable species within the community's forest, including the Chiapas pine (Pinus chiapensis), logging occurred, but has been minimal and community lands have therefore remained highly forested. Between 1965 and 1968 the timber company Etla logged areas of Patula pine (Pino patula), known as Mexican Weeping Pine. However, the community did not see any benefits from this enterprise, because of corruption from a former community leader, and decided not to continue the contract. The community has since been working 
to restore damaged and deforested areas, and has partaken in reforestation projects to replace lost pine species. They have focused on conservation and are now receiving payments for hydrological services because of their conservation of forests in the headwaters of the country's second largest watershed, the Papaloapan (Poleman, 1964).

Santa Cruz Tepetotutla is home to people from the Chinantec ethnic group, who have inhabited the Chinantla Alta region for over a thousand years (Bray et al., 2008; Bevan, 1938). The native language is Chinanteco, a tonal language that is part of the Otomanguean language family. It is used in areas where some of the earliest signs of Mesoamerican agriculture are found (MacNeish, 1967). It is believed that Olmec cultures have been in the Chinantla since at least 500 B.C., although the hyper humid conditions have hindered archaeological exploration (Martin, 1996).

According to community documents (ERA A.C., 2000), there were prehispanic constructions in the area known as El Mogote, but no one is sure exactly when it was built. In the 1920 's the community of Santa Cruz Tepetotutla was in a location known now as pueblo viejo or the old town. The town relocated after smallpox and dysentery killed an estimated 350 of the community's 500 inhabitants. Survivors organized themselves and rebuilt their community in the current location of Santa Cruz Tepetotutla and construction continued through the following decades.

The first school was completed in 1969 and by 1973 the community had potable water brought in through pipes from the fresh mountain springs. A large airstrip was built in 1984, running down one of the ridges adjacent to the community. Construction of a road was authorized in 1984, however it was not completed for almost twenty years. Electricity reached Santa Cruz Tepetotutla in 1991, and by 1994 phone lines had been 
added. A health clinic was built in 1996, as well as two additional schools, so children no longer needed to leave the community for primary and secondary education.

\section{COMMUNITY CONSERVATION}

Santa Cruz Tepetotutla is one of seven communities with an ICCA, which have organized themselves into a regional organization known as the Comité Regional de Recursos Naturales de la Chinantla Alta, or the Natural Resource Committee of the Upper Chinantla (CORENCHI). They are better able to effectively coordinate conservation activities with NGO's and governmental agencies at the national level through their collective efforts. These seven communities have a collective land area of 33,921 ha, with a total of over 27,000 ha certified in their individual community protected areas (Bray et al., 2008). Land-use decisions among CORENCHI members are focused on conservation, making them unique among other communities that focus on extraction and livestock rearing (Figel, 2008). Conservation has been successful because Chinantec communities have clearly defined geographic boundaries, a primary focus on conservation, a legal means for governance, an existing body of rules and a definitive organization with governing authority (Figel, 2008).

As a result of the collective effort to conserve large tracts of forest in the Sierra Norte, CORENCHI communities now receive payments for hydrological services (PSAH). The PSA-H program, administered by the National Forestry commission (CONAFOR), began in 2003 to curb its top two environmental problems, deforestation and water scarcity (Muñoz et al., 2004) through better land management practices. Santa Cruz Tepetotutla enrolled the maximum amount of 4000 ha in the program in 2004, 
receiving \$32 USD per hectare annually for a five-year contract period. At the time of this study, Mexico's largest brewery was also in discussions with CORENCHI over hydrological payments programs because the community protects the source of its water. Approximately 160 of the Santa Cruz Tepetotutla's 730 inhabitants are legal community members who participate in the community assembly. Under Mexican agrarian law, only heads of household enrolled in the official community roster (padron) are allowed to vote in the assembly. Each of the assemblies of CORENCHI have independently determined the allotment of their payments for hydrological service funds. In Santa Cruz Tepetotutla, they decided that administration would receive $6 \%$ of the funds, $2.5 \%$ would be for CORENCHI operations, $3 \%$ for student scholarships, and $10 \%$ directly to conservation efforts. The remaining $78.5 \%$ is saved in a bank until it is distributed to community members on an annual basis. In case of emergencies or illnesses, a community member may request their funds earlier, but the comisariado is charged with ensuring even distribution.

Through community initiatives and joint efforts with local and global NGO's, universities and private companies, the community has planned and implemented numerous projects that will further benefit their natural and social capital. Projects include reestablishing organic coffee certification, protecting and reforesting damaged lands, diversifying production with tepejilote (Chamaedorea tepejilote) and other fruits, and providing services for eco-tourism. The Secretariat of Environment and Natural Resources, Secretaría del Medio Ambiente y Recursos Naturales (SEMARNAT), authorized a reforestation plan in 2000 . The plan is to reforest areas of Chiapas pine, hardwoods and softwoods at the rate of 10 hectares annually, for a duration of 10 years. 
Additionally, survey responses indicate that the community would be interested in participating in carbon capture projects for the forested areas that are not covered under the payments for hydrological services program.

\section{AGRICULTURAL AND FORESTRY MANAGEMENT}

Agriculture production in Santa Cruz Tepetotutla includes milpa, beans, coffee, sugar and yucca. Milpa is cultivated through a system of roza-tumba-quema, or slash and burn. Between March and April, the plot is cleaned by hand using a machete, removing all of the herbaceous vegetation. Thicker vegetation is cut or burned, however useful logs are kept for fuel or building materials. Controlled fires burn at the start of the annual rains in May, after a protective guardaraya is built around the plot to prevent the fire's spread. Seeds are planted after the second week of June. Typically fields go through this

rotation every 3 or 4 years, so the soil has time to recuperate between harvests.

Before 1958, sugar was the main cash crop, which was cultivated in a majority of the agricultural zone by approximately $40 \%$ of community members. It was the most commercially important crop until coffee was introduced. Community members, who worked at a French plantation named La Unión Francesa located in nearby San Juan Teponaxtla Cuicatlán, brought coffee. Initially, production methods in Santa Cruz Tepetotutla consisted of traditional polycultures, or "coffee gardens" where coffee was planted near homes or under the natural forest canopy, during the first time period of coffee production. Coffee was also planted in cornfields, however it was at a small-scale level initially. Eventually, in the second coffee period, subsidies from INMECAFE resulted in expansion, which included converting many of the sugar cane fields and 
cornfields into coffee plots that had minimal amounts of shade. This time period in Santa Cruz Tepetotutla saw the most amount of vegetational cover change, although many farmers reported planting additional shade trees with their coffee at this time.

In response to the coffee crisis, in the third coffee period (1990 - Present), a new set of relationships between social and ecological variables in the coupled system emerged when a considerable number of farmers in Santa Cruz Tepetotutla began to abandon their coffee farms or change back to corn or other production (Pedro Osorio, pers. comm.). Many fields were left unharvested and there was a simultaneous increase in emigration. Between 1990 and 1995, it was estimated that $25 \%$ of the community left to work in Oaxaca, México D.F., or Los Angeles, California (ERA A.C., 2000), although the community's statutes require members to regularly participate in cargos and tequios, under their system of usos y costumbres. Therefore many of those that initially emigrated, returned to fulfill their duties, limiting some of the emigration to a temporary basis. A recent census carried out by the Ministry of Health concluded that young families in the community are unstable as a result of the high rates of emigration.

Six different pathways of change produced during the third period in the coffee landscape were identified in this study, which have allowed farmers to diversify or shift production to curb reliance on coffee. The resulting mosaic landscape within the agricultural zone is illustrated in the following photographs taken during research. 

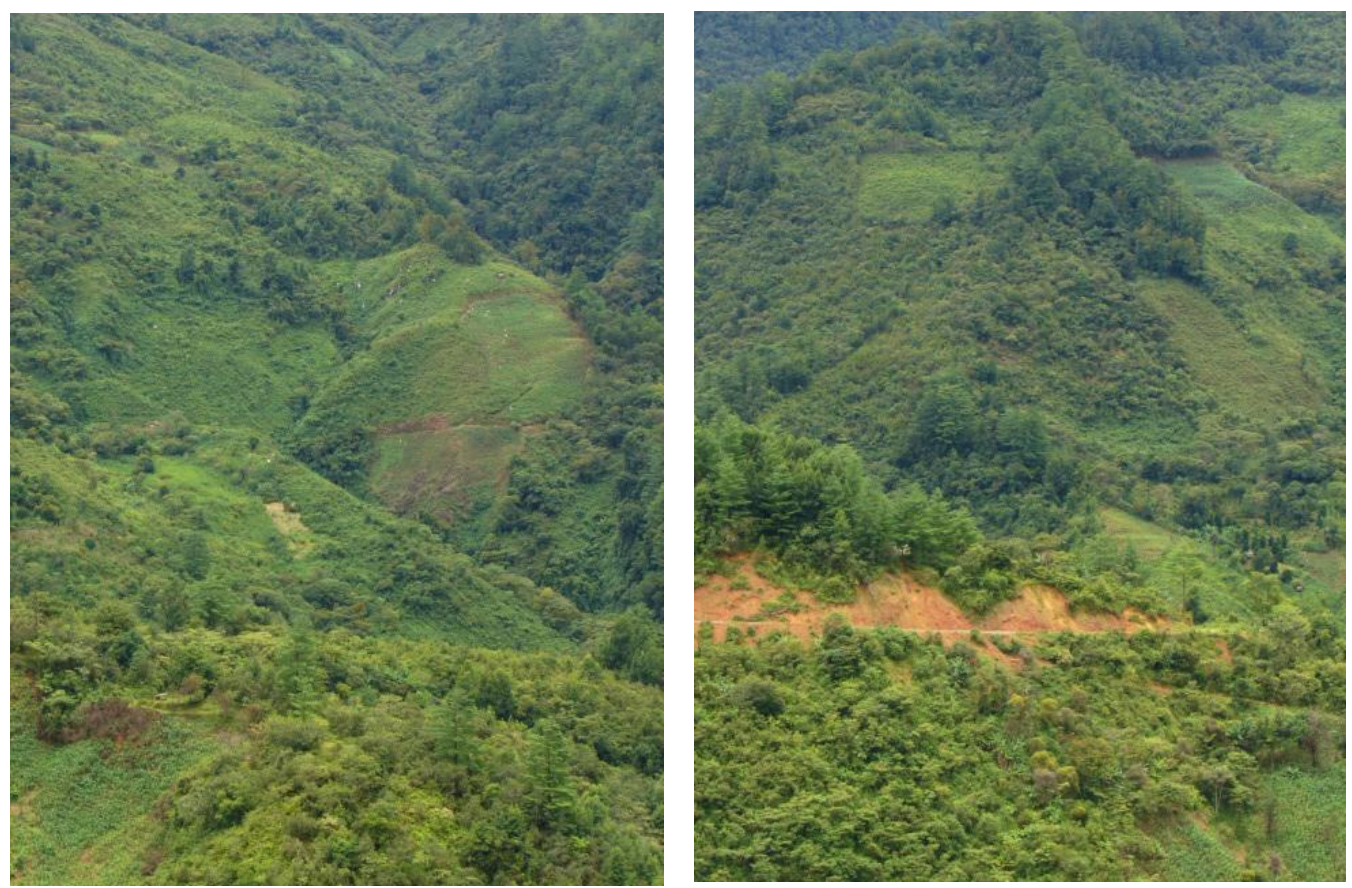

Figure 2.4 Photographs of Santa Cruz Tepetotutla's Agricultural Zone (C) Emily Hite

The road that arrived in Santa Cruz Tepetotutla in 2003 eliminated approximately 12-15 hectares of coffee plots. When it was expanded to the neighboring community of San Antonio el Barrio in 2008, an additional 25-30 hectares were lost in Santa Cruz Tepetotutla's agricultural zone. Additional plots below the road are considered to be under restoration or natural recuperation because of the excess damage and erosion caused by construction and are slowly being covered in secondary succession vegetation.

The community has identified five types of forest on their lands, including patches of Chiapas pine (Pinus chiapensis), Patula pine (Pinus patula), bosque mesofilo, evergreen tropical and secondary forests (ERA AC., 2000). Forty year old Chiapas pine forests comprise 544 ha, which were the most disturbed areas because they had previously been heavily used for building homes. The community recognizes that its population is low throughout Mexico, and special consideration is needed to conserve and expand its range. They have established an internal community agreement to work 
towards improving its habitat within their lands. Patula pine forests cover 951 ha, which had also previously exploited. Although its wood is not as valuable as the Chiapas pine, and is further from the community, it is an area they might utilize for timber production in the future as a form of economic diversification.

Bosque mesofilo, or tropical montane forest and cloud forest, comprises the largest amount of forest type on the community lands, 6995 hectares. It is found above the community in higher elevations and is described as a transitional zone between the high altitude Patula pine forest and the lower elevation forests. It is a zone that is most frequently studied by researchers, since it is home to high levels of biodiversity. The community hopes to utilize the area by leading eco-tours, which highlight its unique and plentiful flora and fauna. The community also has identified 263 ha of mixed secondary forests and 206 ha of tropical evergreen forests.

Meave del Castillo (1998) studied the vegetational characteristics of Santa Cruz Tepetotutla's forested regions, now conserved in the ICCA, which are illustrated in the following table.

Table 2.1 Vegetational Characteristics of Santa Cruz Tepetotutla

\begin{tabular}{|l|l|l|l|l|l|}
\hline Zone & Location* & Orientation & Slope & Vegetation & $\begin{array}{l}\text { Altitude } \\
(\mathrm{m})\end{array}$ \\
\hline $\mathrm{SC} 1$ & $6.9 \mathrm{~km} \mathrm{~S}\left(166^{\circ}\right)$ & $\mathrm{N}$ & $40^{\circ}$ & Forests of Engelhardia spp. & 1830 \\
\hline $\mathrm{SC} 2$ & $7.6 \mathrm{~km} \mathrm{~S}\left(180^{\circ}\right)$ & $\mathrm{NW}$ & $35^{\circ}$ & Forests of Lauracea spp. & 2260 \\
\hline $\mathrm{SC} 3$ & $10.5 \mathrm{~km} \mathrm{~S}\left(162^{\circ}\right)$ & $\mathrm{N}$ & $35^{\circ}$ & Oak Forests & 2560 \\
\hline $\mathrm{SC} 4$ & $7.6 \mathrm{~km} \mathrm{~S}\left(180^{\circ}\right)$ & $\mathrm{S}$ & $33^{\circ}$ & Oak Forests & 2500 \\
\hline $\mathrm{SC} 5$ & $8.0 \mathrm{~km} \mathrm{~S}\left(170^{\circ}\right)$ & $\mathrm{NW}$ & $10-30^{\circ}$ & Evergreen Forests & 2010 \\
\hline
\end{tabular}

Source: Adapted from Meave del Castillo, 1998.

*Location is direction from Santa Cruz Tepetotutla's center 


\section{RESEARCH METHODS}

I initially intended to study the abandonment of coffee farms in Santa Cruz Tepetotutla, because it was believed that abandonment of coffee fields equated to deserted plots, left completely unused after production ended. However, after preliminary fieldwork, it was recognized that abandonment was just one of the many transitional phases of production, or alternate pathways, of land management that had emerged over the last two decades. A landscape that for at least 20 years in the 1970's and 1980's was continuously producing coffee with limited shade, has transformed into a much more varied vegetative and productive landscape. Coffee plots have been shifting production methods, depending on how household decide to cope with economic and policy influences. Land management decisions on these individual plot scales may have ecological implications for the entire coffee zone and for its connected community and regional lands, therefore ecological and sociological methods were used to study the communities landscape transformations, described below.

\section{ECOLOGICAL METHODS}

Field work was completed with the help of guides, who provided extensive information on the plant diversity of the agricultural zone, ownership, management and were knowledgeable about each farmer's use of their coffee plot. Community member, Pedro Osorio, who had for worked for years as a research assistant for Mexican botanist Jorge Meave, assisted on each transect, providing consistency in plant identification. Raymundo Osorio, another knowledgeable community member, usually accompanied us as well, with occasional help from Raymundo Osorio Junior or other community 
members. Pedro and Raymundo are both knowledgeable of the local and Spanish names of the plants in the region, and have experience in plant identification and voucher collection after working with experienced botanists.

Transect methods were tested in the coffee fields of Santa Cruz Tepetotutla during the two week field course and a variation of the Gentry transect method was chosen (Gentry, 1982). During initial census of the coffee fields with the guides, the agricultural zone was divided into three areas, in relation to the town, west (1), east (2) and south (3). The large expanse of the agricultural zone and personal time constraints required that an even distribution method be used to select plots for this study. Therefore, every fourth plot was chosen on the left and right side of all main trails throughout the agricultural zone. Plots were marked with flagging tape and given a numerical identification code relative to their area and trail. For example, in area 1 , on trail 1, the fifth plot encountered was labeled "1.1.5."

At this time, the plot owner's name, GPS coordinates, local known location name, plot management and cultivation activities, altitude, plot size and slope orientation were recorded on field data sheets (APPENDIX 1). Plot activity included whether it was an actively producing or abandoned coffee plot, how long it had been abandoned, how many times it was cleaned per year, if chemicals or pesticides were used, if it was previously organically certified and if it was a polyculture or monoculture. Plot activities and characteristics were used to create an identifiable "plot type" system, with six identified pathways of change, used for analysis and described in greater detail below. Specific notes were taken on what types of fruits or vegetables were also collected, if firewood was collected or cut, or if any other activity occurred on the plot. 
The average size of each studied coffee plot was 1 ha, and average time to complete one transect was 45 minutes. One transect was used in plots with 1 hectare or less, and 2 transects were used if the plot was more than one hectare. When two transects were used, they were each placed at the center of their respective hectare, so that there was no sampling overlap. The sampling unit was a census of woody plants using $2 \times 50$ meter belt transects. Transects were placed perpendicular to the slope. Every woody individual tree and shrub greater than or equal to $2.5 \mathrm{~cm}$ diameter at breast height (DBH) was recorded, if all or part of its trunk was within the belt. Standard DBH of 1.3 meters from the base of the trunk was used, unless multi-stemmed or forked trunks were encountered. In that case, measurements were taken closer to the base of the trunk and were noted on field data sheets.

All woody individuals were recorded by their Spanish or Chinantec name. A sample of every new species encountered was collected as a voucher, with fruits or flowers if possible. Common species encountered previously were not recollected. Vouchers were sent to Biologist Armando Rincon Rios, a recognized expert on plants of the region, at the Universidad Nacional Autónoma de México (UNAM) for taxonomic identification. Additionally, during transects, slope degrees were recorded with a clinometer and canopy cover was recorded with a densiometer, each at $0 \mathrm{~m}, 25 \mathrm{~m}$ and 50 meters. Both the slope and cover measurements were averaged for each plot to get overall estimates.

Two statistical software programs, SPSS 18 and PAST 2.07, were used to organize and analyze data, which is presented in the third chapter. Analysis included finding correlations or relationships of the vegetation between the six pathways of change. I 
analyzed species and families in each of the plot types with their frequencies, DBH, basal area and the plot's slope degree, orientation and altitude. Shade percentages will be compared as well as diversity and evenness using Simpson's Index of Diversity and the Shannon Weiner Index.

\section{SOCIAL METHODS}

The social research consisted of semi-structured and structured interviews (Appendix 2) modeled after Research Methods in Anthropology 4th edition (Bernard, 2006). Semi-structured interviews were conducted with community leaders on an informal basis. Discussions pertained to the history of coffee production in the community, presence of coffee cooperatives, impact of INMECAFE, emigration and abandonment of coffee production. The time line of coffee events within the community was also discussed in detail. Structured interviews on coffee production were included in a related thesis project, conducted in the same time period, pertaining to the payments for hydrological services that the community members receive (Nieratka, 2011) and included a section on coffee production.

Coffee questions focused on management levels and methods for each plot that they utilized. Size and location of plot were recorded, so that interview answers could be matched to plots that had been studied with transects. All interviewees were asked when they first planted coffee, what was in the plot before they planted coffee, if they planted trees with their coffee, and how much shade their plot had when they first planted coffee. A section of questions focused on the different types of currently producing coffee plots and another section for plots that no longer are used to produce coffee. Interviewees were 
asked how many times they clean their plot, if it was organic, how much coffee they sold the previous year, who they sold coffee to, if they had ever clear cut the plot and when. Those with abandoned plots were asked why and when the plot was abandoned or changed into annual agriculture, if someone had to emigrate because of that shift, and if they planned to cut the plot and replant it in the future. Farmers with any types of coffee plot were additionally asked if they used the plots for any other activity such as fruit or wood collection.

The goal of the structured interviews was to determine the link between the biodiversity and vegetation cover changes in individual plots, the presence of secondary succession forests and household emigration and decision-making. Forest recovery can be correlated to the various household decisions that led to changing production methods and to emigrate, which will help to understand the landscape dynamics, regrowth abilities and the future vulnerability to land-use changes. In cases where ecological and sociological data were collected on the same coffee plot, answers were correlated. However, uncorrelated data was analyzed as well so that an overview of management and production among community members could be assessed. 


\section{CHAPTER III.}

\section{RESULTS AND ANALYSIS}

This chapter is divided into two main sections. In the first section, the results and analysis of the ecological data are presented. The second section presents the results and the analysis of the social data.

\section{ECOLOGICAL RESULTS AND ANALYSIS}

After the initial phase of surveying and marking coffee plots, six different outcomes, or pathways for the transformation of the coffee landscape resulting from the international coffee crisis that began in the late 1980's were identified, resulting in a new dynamic state for the coupled human and natural system.

The classification of plot types is founded on the basis of the various management levels, techniques and plot activities that are currently being used in the sampled plots. Every effort was made to include every type of plot throughout the coffee zone, but there may be additional categories that were not detected. It was essential to create a category system that could be used in analysis. The following are the six plot types, or pathways, defined for this study and their corresponding number code that was used in analysis:

1. Abandoned: Coffee production, as well as most aspects of management, have ceased; however, in all abandoned coffee fields studied, the owner continued to collect firewood, either dead or from live trees, and almost all farmers harvested other plants for consumption. These plots may have previously been any of the other types of plots listed below, however, in this study, none of the abandoned plots were previously annual agriculture plots. 
2. Passive Organic: coffee production is still occurring and may be used for commercial sale; cleaned, or weeded, at least two times per year, and were in earlier years certified as organic by CEPCO. Even though the farmer continues to follow organic practices, it is no longer certified as organic, and is therefore referred to as "passive." The owner may collect firewood or other plants for consumption from the plot, which was noted on the data sheet.

3. Semi-Active Conventional: coffee production is still occurring and may be used for commercial sale; it is considered partially abandoned, in that the owner cleans the plot only one time per year. Traditional methods (aka "conventional" methods) are used for production. It was never certified as organic. Fruits, vegetables and firewood also may be collected from these plots.

4. Active Conventional: coffee production is still occurring and may be used for commercial sale; cleaned at least two times per year. It was never certified as organic by CEPCO. Traditional (conventional) methods are used for production, and plants and firewood may be collected.

5. Annual Agriculture: no coffee produced; plot has been cut down and burned so that all vegetation was completely removed. It has been completely converted into an annual agriculture plot. Typically corn was planted, although some farmers chose to plant yucca. This is the only category that is a monoculture, as there are no other trees or plants within the plot, and no other products are collected. 
6. Mixed: may still be producing coffee; encompass two of the above-mentioned categories. They occur when a farmer decides to split his plot into two or more sections, and farm each of those sections differently. At this study site, the following mixed plots were sampled: one abandoned and semi-active plot; two abandoned and annual agriculture plots; two semi-active and annual agriculture plots; and three annual agriculture and active conventional plots. Transects nonetheless ran through the middle of the plot, without regard to location of the sections. The types of plot mixed were noted for each mixed plot.

Fifteen days were spent in the field carrying out transect sampling. The even distribution and numerical identification code systems, discussed in the methodological section, were used to mark 51 plots. There were 19 plots marked in area one, 26 plots in area two, and 6 plots in area three. Figure 3.1 shows the GPS locations of marked plots within a Google image. The three surveyed areas are circled and labeled also. (Some marked plots are close together and are not distinguishable from other plot locations).

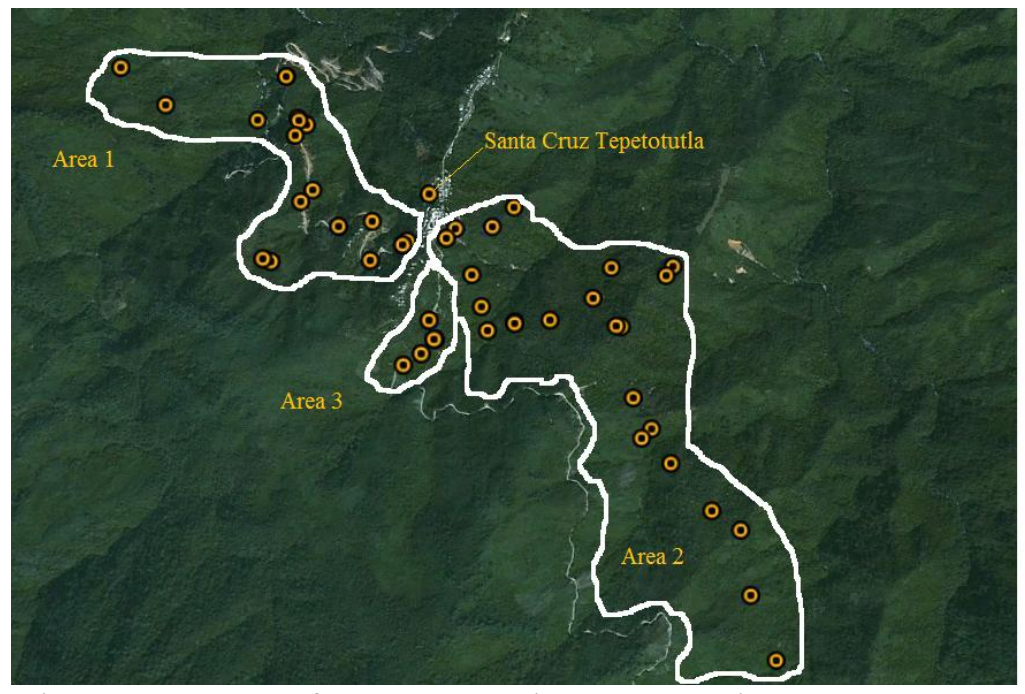

Figure 3.1 Map of Transect and Area Locations 
Table 3.1 summarizes the number of plots and transects that were completed in each of the plot type categories. Note that the number of transects differs from the number of plots marked because no transects were completed in annual agricultural plots since they lacked woody vegetation. In addition, two abandoned, one passive organic, one semi-active conventional and two mixed plots had more than one hectare and two transects were used, as described in the methodology section. Table 3.1 lists the total number of hectares within the selected plots used in this study for each plot type as well. The average plot size was 1 ha, although sizes ranged from 0.25 ha to over 2 ha. With 410 hectares utilized for coffee, this represents approximately $18 \%$ of the coffee zone. A transect of $2 \times 50$ meters equates to 0.01 hectares, resulting in a thorough survey of 0.49 hectares in total.

Table 3.1 Distributions of Plot Types and Transects

\begin{tabular}{|l|l|c|c|c|c|}
\hline \multicolumn{2}{|c|}{ Plot type } & \# of Plots & $\begin{array}{c}\text { \% of Coffee } \\
\text { Zone Sampled }\end{array}$ & \# of Transects & Total ha. \\
\hline 1 & Abandoned & 16 & 31 & 18 & 20.5 \\
\hline 2 & Passive Organic & 6 & 12 & 7 & 10.5 \\
\hline 3 & $\begin{array}{l}\text { Semi-Active } \\
\text { Conventional }\end{array}$ & 9 & 18 & 10 & 10.5 \\
\hline 4 & Active Conventional & 4 & 8 & 4 & 2.5 \\
\hline 5 & Annual Agriculture & 8 & 16 & 0 & 11.75 \\
\hline 6 & Mixed & 8 & 16 & 10 & 16.25 \\
\hline Total & & 51 & & 49 & 72 \\
\hline
\end{tabular}

Transects resulted in 751 individual woody plants being documented and 105 plant vouchers being collected. Identification by UNAM botanist Armando Rincon Rios suggested that there were 32 families. Each family was given a numerical ID (1-33) for 
analysis (the $33^{\text {rd }}$ family is represented by a group of species that did not have a family identified and are labeled as "ND" for Not Determined). There were 82 species identified, and each species was given a numerical label (1-82) for analysis. Table 3.2 lists each plant recorded by its family name, genus and species followed by its local name and ID number. Plants whose family, genus or species were not identified, but did have a known local name, are signified by "ND," which stands for "Not Determined." The plants labeled "no name" correspond to plants that were not identified with local names by the guides, however, some were identified by Biologist Armando Rincon Rios. Table 3.2 Scientific and Common Names of Plants

\begin{tabular}{|c|c|c|c|c|}
\hline Family & Genus & Species & Local name & $\begin{array}{l}\text { Spec } \\
\text { ies } \\
\text { ID }\end{array}$ \\
\hline Actinidaceae & Saurauia & Saurauia scabra & moco & 52 \\
\hline Altingiaceae & Liquidambar & $\begin{array}{c}\text { Liquidambar } \\
\text { styraciflua }\end{array}$ & pina bete & 78 \\
\hline Anacardiaceae & Spondias & Spondias puperea & ciruela & 24 \\
\hline Anacardiaceae & Spondias & Spondias spp. & ciduela dulce & 25 \\
\hline Anacardiaceae & Mangifera & Magnifera indica & mango & 41 \\
\hline Anacardiaceae & Spondias & Spondias spp. & mango criollo & 42 \\
\hline Annonaceae & Guatteria & Guatteria galeottiana & $\begin{array}{c}\text { chico zapote amarillo } \\
\text { de bosque and chico } \\
\text { zapote de monte }\end{array}$ & 20 \\
\hline Asteraceae & Telantophora & $\begin{array}{c}\text { Telantophora } \\
\text { grandiflora }\end{array}$ & mano de tigre & 43 \\
\hline Asteraceae & Eupatorium & Eupatorium spp. 1 & no name 3 & 58 \\
\hline Asteraceae & Eupatorium & Eupatorium spp. 2 & no name 5 & 59 \\
\hline Asteraceae & Verbesina & $\begin{array}{c}\text { Verbesina } \\
\text { turbacensis }\end{array}$ & no name 4 & 60 \\
\hline Asteraceae & Senecio & Senecio arborescens & palo de tigre & 74 \\
\hline Asteraceae & Verbesina & Verbesina spp. & palo escalera & 76 \\
\hline Asteraceae & Bacharis & Bacharis spp. & palo secante & 77 \\
\hline
\end{tabular}




\begin{tabular}{|c|c|c|c|c|}
\hline Balsaminaceae & Impatiens & Impatiens spp. & balsam & 17 \\
\hline Burseraceae & Protium & Protium spp. & arbol de bosque & 10 \\
\hline Chloranthaceae & Hedyosmum & $\begin{array}{c}\text { Hedyosmum } \\
\text { mexicanum }\end{array}$ & palo de agua & 67 \\
\hline Clethraceae & Clethra & Clethra spp. & arbol de tierra & 14 \\
\hline Clethraceae & Clethra & Clethra mexicana & palo de tierra & 73 \\
\hline Ebenaceae & Diospyros & Diospyros digyna & $\begin{array}{c}\text { chico zapote amarillo } \\
\text { de niño and chico } \\
\text { zapote negra }\end{array}$ & 21 \\
\hline Erythroxylaceae & Erythroxylum & Erythroxylum spp. & drueno & 27 \\
\hline Erythroxylaceae & Erythroxylum & $\begin{array}{c}\text { Erythroxylum } \\
\text { tabascense }\end{array}$ & no name 1 and 2 & 57 \\
\hline Euphorbiaceae & Croton & Croton draco & palo de sangre & 71 \\
\hline Euphorbiaceae & Alchornea & Alchornea latifolia & rosario & 81 \\
\hline Fabaceae & Inga & Inga latibracteata & $\begin{array}{c}\text { cuajinicuil and } \\
\text { cuajinicuil de tejon }\end{array}$ & 26 \\
\hline Fabaceae & Calliandra & $\begin{array}{l}\text { Calliandra } \\
\text { grandiflora }\end{array}$ & palo de frijole & 69 \\
\hline Fabaceae & Erythrina & Erythrina spp. & sonpancla & 82 \\
\hline Fagaceae & Quercas & Quercas spp. & pajarillo blanco & 63 \\
\hline Flacourtiaceae & Trema & Trema micrantha & capulin & 18 \\
\hline Hypericaceae & Vismia & Vismia mexicana & palo amarillo & 65 \\
\hline Hypericaceae & Vismia & Vismia spp. & $\begin{array}{c}\text { palo amarillo corazon } \\
\text { dulce }\end{array}$ & 66 \\
\hline Lauraceae & Persea & Persea schiedeana & aguacate chinene & 1 \\
\hline Lauraceae & $N D$ & $N D$ & aguacate criollo & 2 \\
\hline Lauraceae & $N D$ & $N D$ & aguacate de bolla & 3 \\
\hline Lauraceae & Beilshmedia & Beilshmedia anay & aguacate dulce & 4 \\
\hline Lauraceae & $N D$ & $N D$ & $\begin{array}{c}\text { aguacate dulce de los } \\
\text { morados }\end{array}$ & 5 \\
\hline Lauraceae & $N D$ & $N D$ & aguacatillo & 6 \\
\hline Lauraceae & $N D$ & $N D$ & aguacatillo de bosque & 7 \\
\hline Lauraceae & Ocotea & Ocotea leucoxylon cf. & aguacatillo negro & 8 \\
\hline Lauraceae & $N D$ & $N D$ & aguacatillo rojo & 9 \\
\hline Lauraceae & $N D$ & $N D$ & $N D$ & 37 \\
\hline Malvaceae & Heliocarpus & Heliocarpus spp. 1 & jonote & 35 \\
\hline Malvaceae & Heliocarpus & Heliocarpos spp. 2 & jonote blandito & 36 \\
\hline
\end{tabular}




\begin{tabular}{|c|c|c|c|c|}
\hline Melastomataceae & Miconia & Miconia spp. 7 & miconia & 44 \\
\hline Melastomataceae & Conostegia & Conostegia spp. & miconia (edible) & 45 \\
\hline Melastomataceae & $N D$ & Miconia spp. 1 & miconia de arena & 46 \\
\hline Melastomataceae & $N D$ & Miconia spp. 2 & miconia de barra & 47 \\
\hline Melastomataceae & $N D$ & Miconia spp. 3 & $\begin{array}{c}\text { miconia de hojas } \\
\text { grande }\end{array}$ & 48 \\
\hline Melastomataceae & Miconia & Miconia spp. 4 & miconia de liso & 49 \\
\hline Melastomataceae & $N D$ & Miconia spp. 5 & miconia dulce & 50 \\
\hline Melastomataceae & $N D$ & Miconia spp. 6 & miconia (not edible) & 51 \\
\hline Moraceae & Pseudolmedia & Pseudolmedia spuria & $\begin{array}{l}\text { arbol de durasno de } \\
\text { monte }\end{array}$ & 12 \\
\hline Myriacaceae & $N D$ & $N D$ & pajarillo & 62 \\
\hline Myriacaceae & $N D$ & $N D$ & pajarito & 64 \\
\hline Myrtaceae & Psidium & Psidium guajava & guayaba & 30 \\
\hline Myrtaceae & Sysygium & Sysgium jambos & pomarosa & 80 \\
\hline Pinaceae & Pinus & Pinus chiapensis & pinus chipensus & 79 \\
\hline Piperaceae & Piper & Piper spp. & durasno & 11 \\
\hline Proteaceae & Roupala & Roupala montana & encino de puno & 28 \\
\hline Rosaceae & Eriobotrya & Eriobotrya japonica & nispero & 56 \\
\hline Rubiaceae & Psychotria & $\begin{array}{l}\text { Psychotria } \\
\text { trichotoma }\end{array}$ & palo de muerto & 70 \\
\hline Rutaceae & Citrus & Citrus reticulata & mandarina & 40 \\
\hline Rutaceae & Citrus & Citrus aurantium & naranja & 54 \\
\hline Rutaceae & $N D$ & $N D$ & naranja criollo & 55 \\
\hline Sapotaceae & Manikara & Manikara spp. & chico zapote de bosque & 22 \\
\hline Sapotaceae & $N D$ & $N D$ & chico zapote de niño & 23 \\
\hline Sapotaceae & Manilkara & Manikara sapota & mamey & 39 \\
\hline Siparunaceae & Siparuna & Siparuna spp. & palo de carne & 68 \\
\hline Solanaceae & $N D$ & $N D$ & $\begin{array}{c}\text { huele de la noche } \\
\text { (edible) }\end{array}$ & 31 \\
\hline Solanaceae & Cestrum & Cestrum nocturnum & huele de noche & 33 \\
\hline Solanaceae & Solanum & $N D$ & $\begin{array}{c}\text { huele de la noche de la } \\
\text { bosque }\end{array}$ & 34 \\
\hline Urticaceae & $N D$ & $N D$ & arbusto de sapo & 16 \\
\hline Urticaceae & Cecropia & Cecropia spp. & changarro & 19 \\
\hline Urticaceae & Urera & Urera elata & mala mujer & 38 \\
\hline
\end{tabular}




\begin{tabular}{|c|c|c|c|c|}
\hline Urticaceae & $N D$ & $N D$ & palo de sapo & 72 \\
\hline ND & $N D$ & $N D$ & arbol de flor & 13 \\
\hline ND & $N D$ & $N D$ & $\begin{array}{c}\text { arbusto de fruta de } \\
\text { cidil }\end{array}$ & 15 \\
\hline ND & $N D$ & $N D$ & flor de escalera & 29 \\
\hline ND & $N D$ & $N D$ & $\begin{array}{c}\text { huele de noche (not } \\
\text { edible) }\end{array}$ & 32 \\
\hline ND & $N D$ & $N D$ & namakati & 53 \\
\hline ND & $N D$ & $N D$ & no name 6-11 & 61 \\
\hline ND & $N D$ & $N D$ & palo de treno & 75 \\
\hline
\end{tabular}

Nine families are represented in one plot type, including Annonaceae, Balsaminaceae, Fagaceae, Moraceae, Pinaceae, Piperaceae, Protaceae, Rosaceae and Siparunaceae. They represent 21 individual plants, or $2.8 \%$ of the total documented plants. Four families are represented in two plot types including, Burseraceae, Chloranthaceae, Erythroxylaceae and Sapotaceae. Together they represent 31 individuals, or $4.1 \%$ of the total. Three families are represented in three plot types, including, Altingiaceae, Ebenaceae and Rubiaceae. They include 79 individuals, or $10.5 \%$ of the total. Ten families are represented in four plot types, including, Actinidaceae, Anacardiaceae, Asteraceae, Chlethraceae, Flacourtiaceae, Malvaceae, Melastomataceae, Myrtaceae, Rutaceae and Solanaceae. They include 308 individuals, or $41 \%$ of the total. The 28 "ND" plants are also represented in four plot types, representing $3.7 \%$ of the total. Six families are represented in five plot types including, Euphorbiaceae, Fabaceae, Hypericaceae, Lauraceae, Myriacaceae and Urticaceae. They represent 284 individuals, or $37.8 \%$ of the total plants documented.

Biodiversity indexes were used to compare family distribution. Diversity indexes measure the species diversity in a community and also take into account the relative 
abundances of different species. They provide information about rarity and commonness and help describe community structure. They are used here to describe the diversity and evenness within each of the plot types. Since some calculations have natural bias, and may provide more weight to habitats with unique or rare individuals, a variety of ecological calculations were used to address that issue and ensure that calculations are robust. A combination of SPSS 18 and PAST 2.07 statistical software programs were used. Figures 3.2 and 3.3 illustrate the species Shannon and Simpson diversity calculations, respectively. Plot type 5, annual agriculture, had zero vegetation other than its monoculture crop, so there is no diversity and is not included in either figure.

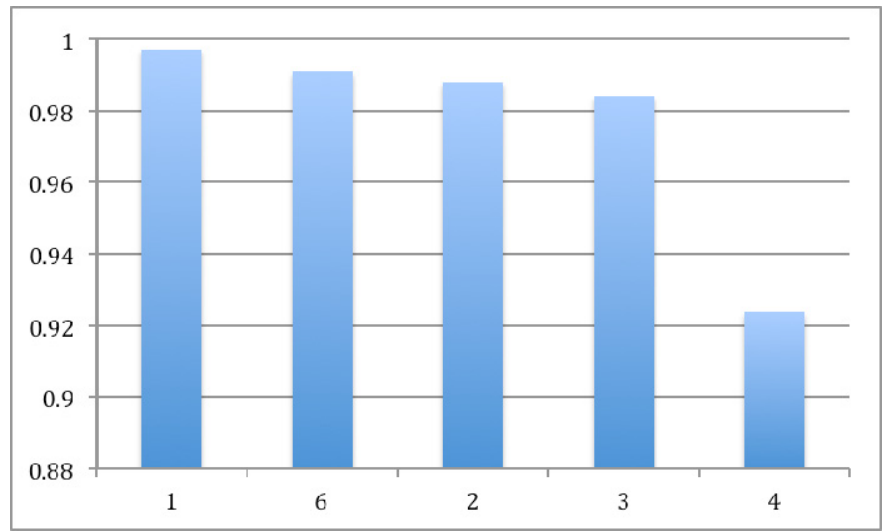

Figure 3.3 Simpson Diversity per Plot Type

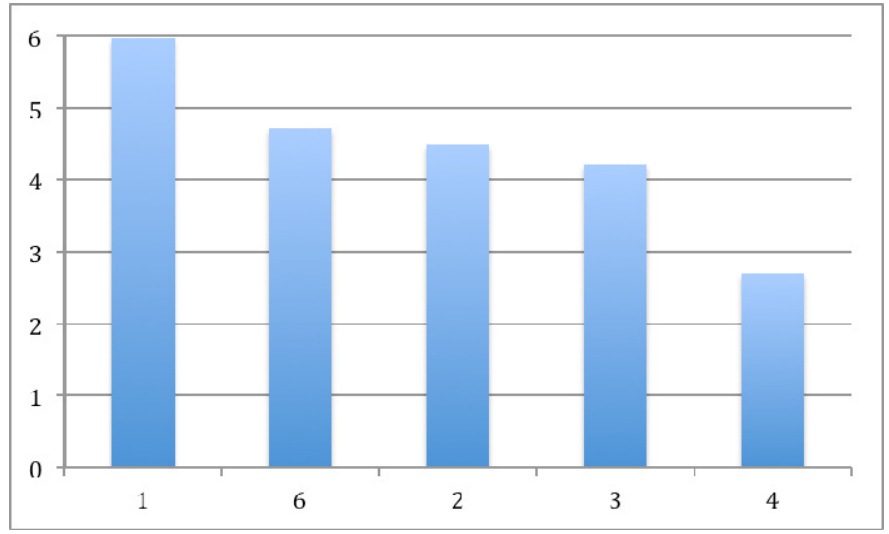

Figure 3.2 Shannon Diversity per Plot Type 
The Shannon (H) and Simpson (1-D) indexes measure the species richness and the evenness in each plot type. The Simpson Index measures the probability that two individuals from a plot will belong to the same species with results yielding values from 0 to $1 ; 1$ representing infinite diversity and 0 representing no diversity. It aims to give an unbiased estimate of the dominance, diversity and evenness of the entire community. The Shannon Index was used to describe the heterogeneity of plot types with results ranging from 1.5, which represents low richness and evenness, to 3.5 , which is high richness and evenness. Plots 1, 2, 3 and 6 each had an index of over 3.5.

The Kruskall-Wallis test is a non-parametric ANOVA test used to compare the medians of several groups, which gives the probabilities that samples are from populations with equal medians. The Kruskall-Wallis test showed that species, DBH, slope degree, shade, altitude and slope orientation were statistically different between each of the plot types with a $99 \%$ confidence level $(p<0.01)$. It did not show a significant difference between family types and plot type $(\mathrm{p}=0.315)$.

Pearson bivariate correlations were used to compare many of the variables for each plot type as well. With a $99 \%$ confidence $(\mathrm{p}<0.01)$, DBH, slope, shade, altitude and slope orientation were significantly different for each plot type. Pearson correlations did not show a significant difference for family $(\mathrm{p}=0.579)$ or species $(\mathrm{p}=0.370)$ between plot types. Pearson correlations also calculated with $95 \%$ confidence a significant relationship between each of the following variables: shade and species; shade and family; shade and slope orientation; species and altitude; species and slope degree.

Kolmogorov-Smirnov non-parametric tests were used to test for overall equal distribution of species in the six plot types, since there was a discrepancy in the results of 
the Kruskall-Wallis and Pearson correlations. The following 5 pairs of plots were determined to be statistically different based on this test with a $95 \%$ confidence level $(p<0.05)$ : abandoned and passive organic; abandoned and semi-active conventional; abandoned and active conventional; passive organic and semi-active conventional; and passive organic and mixed.

There was a 270-meter range in altitude in sample plots, between 923 and 1193 meters above sea level, averaging 1094 meters. Slope degree ranged from 20 to 45 degrees, averaging 30 degrees among all plots. Plot types were also compared using their canopy cover, or vegetational cover, shade averages. Table 3.3 summarizes the percent of shade for each plot type (the measurements of canopy cover in each transect were averaged to get a shade percent for that plot, and then all the plot averages for each plot type were averaged). Since no trees were found in the annual agriculture plots, there was zero percent shade cover. Pearson correlation using SPSS calculated that the shade percentages in different plot types are statistically different $(p<0.01)$.

Table 3.3 Percent of Shade Cover per Plot Type

\begin{tabular}{|l|l|c|}
\hline \multicolumn{2}{|l|}{ Plot Type } & \% Shade Cover \\
\hline 1 & Abandoned & 80.34 \\
\hline 2 & Passive Organic & 75.67 \\
\hline 3 & Semi-Active Conventional & 64.49 \\
\hline 4 & Active Conventional & 39.38 \\
\hline 5 & Annual Agriculture & 0 \\
\hline 6 & Mixed & 61.15 \\
\hline
\end{tabular}

The difference in shade between the two types of conventional plots may be attributed to the number of times that they are cleaned. Active conventional plots are 
weeded, and cleaned out twice as much as semi-active conventional, and therefore, saplings may be cut before they are able to reach maturity.

Table 3.4 Basal Areas per Plot Type

\begin{tabular}{|r|c|c|c|c|c|c|c|}
\hline PLOT TYPE & 1 & 2 & 3 & 4 & 5 & 6 & Total \\
\hline BASAL AREA & 422.5 & 623.79 & 220.48 & 88.12 & 0 & 279.04 & 1633.93 \\
\hline
\end{tabular}

*Basal area calculated by: $\mathrm{DBH}^{\wedge} 2$ x 0.005454 ; results in meters squared.

Within the coffee landscape, an estimated 14\% was sampled during this study (57 hectares $/ 410$ total hectares). Abandoned plots represent $31 \%$ of the coffee landscape, followed by semi-active conventional plots representing $18 \%$, annual agriculture and mixed each with $15.5 \%$, passive organic with $12 \%$ and active conventional with $8 \%$ representation. With $12 \%$ of the mixed plots producing coffee, $50 \%$ of the landscape is producing coffee, and $50 \%$ is no longer producing coffee as an abandoned or annual agriculture plot (including the $3.5 \%$ of mixed plots that are not producing). The limited amount of production in the entire coffee landscape illustrates the very substantial transition in the coupled system from the 1970's-1980's period when the entire landscape $(100 \%)$ was reported to be actively producing coffee. One third of the samples are from abandoned coffee plots, which also have the greatest amount of species biodiversity and vegetational cover. Additional landscape analysis is calculated from responses to the coffee questions in the structured survey. 


\section{SOCIAL RESULTS AND ANALYSIS}

During the same 8-week period, I conducted household surveys that were also constructed to collect data on payments for hydrological services (Nieratka, 2011). All economic questions in the survey focused on household activities for the 2009 calendar

year. A total of 59 surveys were completed with community members. Guides introduced my work to the head of the house and often assisted by translating. Interviews were documented on paper, and generally lasted 40 minutes to one hour. Surveys were held with the head of the household or someone present who was knowledgeable about the family income, employment and farming. The age of interviewees ranged from 26 to 81 years old.

The average household size was 3.6 people, with an average annual income of $34,807$ pesos, roughly 2,900 US dollars ( $1 \mathrm{USD}=12 \mathrm{MXN})$. An estimated $74 \%$ of the household annual income is from either a government subsidy program or the payments for environmental services program (PSA-H), with approximately $37 \%$ from the PSA-H program. Additionally, 27 families (46\%) reported receiving remittances from family members that had emigrated. The amount of remittances ranged averaged 7,672 MXN (\$640 USD) for the year. That equates to approximately $19 \%$ of their annual income. Other income sources are small-scale fruit, honey, livestock or coffee sales.

Thirty-five houses, out of the 59 surveyed (59\%), sold coffee in 2009, which amounted to less than $6 \%$ of their annual income. Since it is widely reported that coffee was the principal source of cash income during the INMECAFE period, this is a striking measure of the collapse of the coffee economy in the region. Seventeen of those sold their coffee to the local cooperative, La Luz de la Chinantla, and 17 sold to coyotes. One 
household sold to a different, unnamed source, while 2 respondents sold coffee to both the cooperative and a coyote. The mean price paid by the cooperative was 21 pesos per kilo ( $\$ 0.80$ per pound USD), although five households reported that they had not yet received payments from the cooperative. The average price paid by the coyotes was 29 pesos per kilo ( $\$ 1.10$ per pound USD).

To determine land-use history and intensity, interviewees were asked detailed questions about their coffee plot. At the time that they first planted coffee, there was an average $56 \%$ original shade cover reported, leaving almost half of the agricultural zone minimally shaded. However, 42 interviewees (74\%) stated that they planted more shade trees with their coffee plants, increasing the total amount of shade in the coffee landscape. Planted tree species included fruit and Inga spp., but also some pine, Liquidambar styraciflua and Heliocarpus species.

The following table illustrates the land-use history and current activity of the plots described by interviewees during household surveys, organized by the coffee period in which they were planted. Land-use history activities are listed by the number of households that first planted coffee during that time period, and the total number of plots that they planted. The previous use of coffee plots indicate what the plot was before coffee was first planted, with the corresponding number of plots that were planted for each use-category. The current plot activity columns lists the number of plots that are still producing coffee, which could be passive organic, semi-active conventional, active conventional or mixed plots. The plots that are no longer producing coffee, either annual agriculture plots (type 5) or abandoned plots (type 1) are also listed according to their prior use. 
Table 3.5 Current and Previous Land-use History

\begin{tabular}{|c|c|c|c|c|c|c|c|}
\hline \multicolumn{5}{|c|}{ Land-use History } & \multicolumn{3}{|c|}{ Current Plot Activity } \\
\hline $\begin{array}{l}\text { Time } \\
\text { Period } \\
\text { Planted }\end{array}$ & $\begin{array}{c}\text { \# Houses } \\
\text { that } \\
\text { Planted }\end{array}$ & $\begin{array}{c}\text { Total \# } \\
\text { Plots } \\
\text { Planted }\end{array}$ & $\begin{array}{c}\text { Prior } \\
\text { Use }\end{array}$ & $\begin{array}{c}\# \\
\text { Plots }\end{array}$ & $\begin{array}{l}\text { Producing } \\
\text { Coffee }\end{array}$ & $\begin{array}{l}\text { Plot } \\
\text { Type } \\
5\end{array}$ & $\begin{array}{c}\text { Plot } \\
\text { Type } \\
1\end{array}$ \\
\hline \multirow{3}{*}{$\begin{array}{c}\text { Early } \\
1950-1969\end{array}$} & \multirow{3}{*}{12} & \multirow{3}{*}{27} & Corn & 19 & 11 & 5 & 3 \\
\hline & & & Forest & 6 & 4 & 2 & 0 \\
\hline & & & Other & 2 & 2 & 0 & 0 \\
\hline \multirow{3}{*}{$\begin{array}{c}\text { Introductory } \\
1970-1989\end{array}$} & \multirow{3}{*}{25} & \multirow{3}{*}{59} & Corn & 18 & 8 & 7 & 3 \\
\hline & & & Forest & 38 & 21 & 8 & 9 \\
\hline & & & Other & 3 & 1 & 0 & 2 \\
\hline \multirow{3}{*}{$\begin{array}{c}\text { Recovery } \\
\text { 1990- } \\
\text { Present }\end{array}$} & \multirow{3}{*}{13} & \multirow{3}{*}{$24 *$} & Corn & 12 & 9 & 3 & 0 \\
\hline & & & Forest & 8 & 6 & 1 & 1 \\
\hline & & & Other & 4 & 1 & 0 & 3 \\
\hline \multirow{2}{*}{ Not known } & \multirow{2}{*}{7} & \multirow{2}{*}{9} & Forest & 7 & 2 & 0 & 5 \\
\hline & & & Other & 2 & 2 & 0 & 0 \\
\hline No Coffee & 2 & 0 & & & & & \\
\hline TOTAL & 59 & 119 & & 119 & 67 & 26 & 26 \\
\hline
\end{tabular}

*During the Recovery Period, 17 of the 24 plots were planted between 1990 and 1992. This may signify a time lag in information transparency. The community members in Santa Cruz Tepetotutla might not have been aware that the ICO quota system had ended or that INMECAFE subsidies were being phased out, especially since the community had limited access to the regional coffee market.

Interviewees described the current management levels of their plots, including how many times they cleaned or weeded it per year, and what other activities they use the plot for. Table 3.6 illustrates the plot type described by community members, which I 
interpreted to fit into the previously described "plot type" category system. Twenty-six members that had active plots described their parcel as being organic and 41 said that it was conventional, however, the term "organic" was not defined during the interview and community members were not asked if their plot was ever certified organic by CEPCO. Fifty-two respondents stated that they had abandoned plots (91\%), which I further broke down into "abandoned" or "annual agriculture" in the table utilizing the descriptive activities that they stated occurred in that abandoned plot. Some mixed plots were discussed during interviews, however, not with enough detail to be able to distinguish them from the other plot types.

Table 3.6 Plot Types Described by Community Members

\begin{tabular}{|l|l|l|}
\hline \multicolumn{2}{|l|}{ Plot Type } & Reported Plots \\
\hline 1 & Abandoned & 20 \\
\hline 2 & Passive Organic & -- \\
\hline 3 & Semi-Active Conventional & 28 \\
\hline 4 & Active Conventional & 39 \\
\hline 5 & Annual Agriculture & 32 \\
\hline 6 & Mixed & -- \\
\hline & TOTAL & 119 \\
\hline
\end{tabular}

Thirty-two respondents stated that the reason for abandonment and conversion to annual agriculture was the drop in the price paid to coffee growers. That equates to $88 \%$ of the abandoned and converted fields being a result of the coffee crisis. Additionally, twelve interviewees stated that a household member had to emigrate because of the coffee prices. A total of 191 household members were named during the 59 household surveys, however, it is difficult to correlate emigration with the total number of 
household members without knowing how many members lived in the house during the time of emigration (community documents state $1 / 4$ of the population emigrated as a result). Much of the emigration was not permanent, and neither is the concept of complete abandonment of coffee production. Out of the 52 households with abandoned plots, $64 \%$ stated that they would re-cut their plot and replant coffee in the future if coffee prices improved. Therefore, the landscape continues to be in flux, more so than in the steady expansion between 1950 and 1990 .

Twenty-three of the interviewees were owners of the plots used for transect studies, which provided for a better understanding of the social and ecological relationship in the agricultural zone. The following table summarizes the survey responses specifically for those households that had one or more of their plots transected. Table 3.7 Coffee Information from Surveyed Households ( $N=59)$

\begin{tabular}{|l|l|l|}
\hline Number of Plots Transected & 27 & 7 \\
\hline Corresponding Plot Types Transected & Abandoned & 3 \\
\cline { 2 - 3 } & Passive Organic & 3 \\
\cline { 2 - 3 } & Semi-Active Conventional & 3 \\
\cline { 2 - 3 } & Active Conventional & 4 \\
\cline { 2 - 3 } & Annual Agriculture & 5 \\
\cline { 2 - 3 } & Mixed & 5 \\
\hline Number of Individual Plants in Plots & $492(66 \%$ of total plants recorded) \\
\hline Previous Land-Use & Corn & 11 \\
\cline { 2 - 3 } & Forest & 11 \\
\cline { 2 - 3 } & Other & 1 \\
\hline
\end{tabular}


Additionally, no correlations were found between emigration and household size, number of children, income or remittances. Those calculations were completed using Pearson's correlations in SPSS. The lack of significant correlations between those factors may not accurately represent the relationships between each of those events. Emigration was recorded for family members that left in the early 1990's and all the income data is from calendar year 2009. All of the results and analysis presented here for ecological and social data will be discussed in further detail in the following chapter. 


\section{CHAPTER IV.}

\section{DISCUSSION AND CONCLUSION}

Indigenous communities in Mexico have been described as having adaptive management systems (Berkes et al., 2000), which exemplify "a conservationist, resilient, permanent, social-ecological system" (Toledo et al., 2003). Those management systems guide crop and livestock selection and the timing of agricultural activities for milpas, non-timber forest resource extraction activities and coffee cultivation (Robson, 2009). The traditional production of coffee in diverse shade matrices of Latin America have been shown to contribute to the social and ecological stability of the region and be important for conservation (Perfecto et al., 2007).

Although the tropical forests of the Sierra Norte have undergone periods of intensive land-use change through deforestation, many communities throughout the region have had an expansion of secondary forests (Gómez-Mendoza et al., 2006). The idea of sustainable forestry management has grown in the region and now community conservation has replaced the logging reputation in the Sierra Norte. However, agricultural subsidies and the international market continue to influence land-use decisions among rural and indigenous farmers. Without a marked improvement and longer term security of coffee prices to growers, it is unlikely that community members will convert to monocultures, and have learned the difficulties of being dependent on a single cash source, evident in their current efforts to diversify financially.

The coffee production subsidies provided by INMECAFE, in addition to the International Coffee Organization's quota system, influenced production methods in rural communities by promoting the shift from traditional subsistence farming and small scale 
commercial sales, into larger-scale commercial production throughout the 1970's and 1980's. Communities throughout southern Mexico capitalized on the growing market and utilized their fertile agricultural lands to become the top coffee-producing region in the country. Numerous communities converted cornfields and forested lands into coffee monocultures, becoming solely dependent on the cash crop to sustain their livelihoods, as their need for cash grew. Those communities were impacted greatly when the coffee market crashed and the subsidy program was phased out in the early 1990's. Responses to the market have been to abandon coffee production and agricultural lands altogether, emigrate, shift production strategies and/or organize into coffee cooperatives. These coping strategies are similar to the ones discussed by Tucker et al. (2010).

Data has shown that $31 \%$ of the coffee zone's production has been completely abandoned, with those plots only currently being used for fruit and wood collection. Only $50 \%$ of coffee plots still produce coffee in the coffee zone, on a small scale compared to historical accounts. Although community reports suggest that an estimated $25 \%$ of the community emigrated as a result of the coffee crisis, structured surveys indicate that $14 \%$ emigrated. $71 \%$ of households stated that they shifted their land-use in the past 20 years, with 53\% stating that the price in coffee is the main reason for their decision, illustrating a connection between the international economy, national policy and landscape change.

Research in other areas of Mexico has suggested that abandoned agricultural plots and their resulting patches of secondary succession dominate some land cover matrices. The agricultural zone in Santa Cruz Tepetotutla, which during the 1960's-1980's was almost $100 \%$ monoculture coffee cultivation with $56 \%$ shade cover, now illustrates a matrix of mixed agricultural patches with specific areas in corn and coffee, including 
areas of early and late secondary succession forests, actively managed and abandoned plots. The initial belief that many coffee and milpa plots were abandoned was a misunderstanding of the actual land-use shift occurring in the community. Numerous, distinct plot transformations were documented in the agricultural zone, highlighting various pathways of change for coffee plots. Community members also reported that active corn plots are never abandoned completely, only left fallow for a few years until another family member or family claims the plot and replants it using slash and burn methods.

The first objective was to determine what pathways of land cover change were experienced by coffee farms in the coffee landscape as a result of the coffee crisis beginning in the late 1980 's, precipitated by the collapse of the ICO and the disappearance of INMECAFE, as well as subsequent emigration and the instability of coffee prices during the third stage, Destabilization and Recovery, of the coupled system. Out of the 59 houses interviewed, $14 \%$ stated that family members had to emigrate because of the coffee price instability. However, the $53 \%$ that stated coffee prices where the reason for their land-use shift illustrates the direct coupled human and natural system dynamics occurring in this community.

The hypothesis that the community heavily relied on coffee as a cash crop, and that the price drop influenced land-use shifts has been supported with data collected at this site. Although emigration was one of the responses to the market, data at this study site does not suggest that it was the dominant response among households. The six pathways of change documented and discussed in this thesis each have distinct management schemes regulating them, which resulted from individual household 
decisions and responses to the coffee market. One of those decisions was to stay in the market, evident in the $50 \%$ of sampled plots that continue to produce coffee.

The six plot transformations labeled in the community are abandoned, passive organic, semi-active conventional, active conventional, annual agriculture and mixed. The two types of conventional plots are similar to the traditional polycultures described by Moguel and Toledo (1999) and the "direct" plot types discussed by Rice (1997). According to household surveys, there are 35 families that sold coffee last year, and there were 27 other active plots described in the community. Coffee is still grown in the active conventional, semi-active conventional, passive organic and mixed plots (which account for $50 \%$ producing for commercial sale), although output and sales are very low compared to historical accounts. Coffee sales are less than $6 \%$ of the total household annual incomes of 2009, which is a substantial decrease considering the community once heavily depended on coffee as their primary cash source.

Abandonment in this community has been defined as just one of the pathways of change in the agricultural zone. A land-use decision for a plot does not equate to a permanent state for that plot. Shifting cultivation practices, new conservation initiatives, and economic factors will influence plot uses. Favorable economic factors (such as long term stability) may lead to a refocus on coffee production, which was concluded from the survey responses that households would re-cut and plant abandoned plots if prices improved. However, the conservation initiatives taken in the past 20 years suggest that biodiversity is important to the majority of community members, and large-scale conversion to monocultures, intensification, or change to a logging regime is unlikely. 
Santa Cruz Tepetotutla has diversified their income portfolios through their landuses, in the past few decades by enrolling in the PSA-H program, partaking in other beneficial reforestation initiatives, planting polycultures, selling honey, fruits and livestock, and creating a basis for eco-tourism. All households responded during surveys that they collected other products from their coffee plots, including fruit and firewood, illustrating the return to more traditional subsistence farming. Remittances may continue to be a much needed source of income, however it may be an irregular source as emigration is also a non-permanent, irregular option for many families.

Organization and the concept of conservation are strong in the community, which may be able to curb long term emigration by requiring community members to regularly participate in cargos. Organization may also assist in gaining organic certification back in the community's coffee plots, which could provide higher prices to growers and promote the conversion into traditional cultivation methods described by Moguel and Toledo (1999). Not only would such an option be favorable economically, but it could also benefit the region in terms of environmental health and increased biodiversity. Out of the types of plots that are still producing coffee at this study site, passive organic plots have the highest levels of biodiversity, shade cover and basal area. If the other types of coffee producing plots were certified as organic in the future, the biodiversity within the coffee landscape and the larger landscape may increase.

This study has distinguished six different plot types, which may be able to contribute to the overall biodiversity in the landscape, since their boundaries abut. There is a much patchier, more structurally diverse landscape now, than existed in the two earlier coffee periods, and there is likely more biodiversity now too. No physical 
boundaries are present that would inhibit the natural flow of resources, such as seed sources, among plot types and the surrounding forested landscape. Annual agricultural plots could be considered to be the only boundaries, however, they are dispersed in a patchy mosaic of agriculture and secondary succession plots, including those with stands of mature trees. Studies have suggested that the combination of such a diverse matrix of secondary succession patches in agricultural zones may contribute to the greater landscape's biodiversity (Bandeira et al., 2005).

The second objective in this study was to determine what the species richness of plants in the coffee landscape is compared between the various pathways of change and what that implies for plant biodiversity and conservation in the larger landscape. The heterogeneity of this coupled human and natural system is illustrated in the land-use shifts through the various pathways of change occurring in the coffee zone of the agricultural area in this community. Abandoned plots have the highest amount of shade cover, the highest number of individuals and the highest number of species and families, signifying nature's resiliency to human decisions and its threshold to land-use changes.

With an average age since abandonment of only 8 years, this could signify the importance of even early age secondary succession forests in the coffee landscape. Longer term studies are recommended to determine how quickly an abandoned field in Santa Cruz Tepetotutla can grow into a mature forest, because there are legacy effects between the time a land-use decision is made and the outcome of its response. The legacy effect and time lag in many systems have been shown to take 30-60 or more years until abandoned lands resemble mature forests (Marcano-Vega, 2002). 
Land-uses throughout the three coffee periods illustrate the connection between local and international policies, economies and household decisions. The international price in coffee was cited as the main reason for shifting cultivation methods, and emigration was one of the ways that households diversified their incomes. Emigration and the subsequent income from remittances, have allowed for farmers to continue to produce coffee, or shift their cultivation methods without needing to be as concerned with coffee prices. The international market resulted in various land-use decisions at the local level during the third coffee period, illustrating a time lag between human and natural couplings. The changes in landscape would not have all been immediately measureable, however, with the information that has come from studying the systems, the community or individual households may be able to make more informed decisions that take into account the future impact their decisions will have on conserving biodiversity. During the 'Introductory Period' of coffee in Santa Cruz Tepetotutla, the coffee landscape began to experience a change, as households added coffee to their production in the agricultural zone. The transition within the agricultural zone to more intense coffee production was slow, until the period of 'Expansion and Stabilization,' when INMECAFE provided subsidies and promoted conversion and the ICO stabilized the market. At this time, households shifted their focus to coffee production and the landscape primarily became a monoculture of coffee, which would not have supported the amount of biodiversity recorded in this study. The third time period of 'Destabilization and Recovery' has seen a great transformation within the coffee zone, through at least six pathways of change that has created a diverse agricultural matrix.

The high levels of biodiversity and shade illustrate the complexity of the coffee 
landscape and are very good statistical measures of the ecological characteristics of the pathways of change. However, those measures are not relevant without comparing each plot type to the other, to determine significant differences. Five sets of plot types, or pathways of change, were determined to be statistically different. This represents how household decisions, based on the international market for coffee, subsequent coffee prices, and agricultural policy, directly impacted the landscape within the coffee zone of this community. Community members had no reason to stop conversion of their corn or forests to coffee until the market crashed, which may be a positive environmental feedback loop if the halt of the conversion of mature forests to monoculture crops are considered.

The conservation concerns and governance system in Santa Cruz Tepetotutla are considered a behavioral shift that increased their social threshold. The decision to conserve their forests, instead of logging them, has resulted in positive impacts on management of the landscape as it passes through transitional stages. The community's decision to conserve large areas of mature forest that border the agricultural zone, may be responsible for the continued high levels of biodiversity found within it. The abundance of different species and families throughout the coffee zone may help maintain the biodiversity in the larger landscape. It will provide seed sources to neighboring plots, as well as plots reached by wind, water or animal dispersion. Dent and Wright (2009) stated that abandoned plots may be able to maintain biodiversity if they are in close proximity to seed sources and have enough time to regrow.

The coffee plots in Santa Cruz Tepetotutla are in close proximity to mature forests 
and likely have seed sources flowing between them, illustrating the nonlinear link between the previous decision to conserve and the current state of the biodiverse coffee zone. Because of the various land-use decisions and their resulting six pathways of change, the exchange of seeds between mature forests, active and non-actively producing coffee plots could be mutually beneficial. I conclude that the transformations within the coffee zone of Santa Cruz Tepetotutla's agricultural area may support the Bandeira et al. (2005) findings that a biodiverse agricultural matrix contributes to the biodiversity of the larger landscape.

The coupled human and natural system in Santa Cruz Tepetotutla serves as an interesting case study that should be expanded upon here, as well as in other parts of Mexico and globally. This system illustrates the dynamic, inseparable relationship among community members, household decisions, responses to market stimuli and their surrounding ecosystem and landscape. Not only do their individual land-use decisions impact the agricultural zone directly, but so do the decisions made on a larger global scale, highlighting the nonlinear relationships, time lags and thresholds involved in coupled human and natural systems. The national subsidizing agency, the international coffee market, consumers, NGO's and coyotes all inadvertently influence biodiversity on a local scale, which can in turn impact the larger landscape through a region's resiliency to changes, and connectivity between various types of landscapes. That is why it is important to increase the amount of research being conducted on coupled human and natural systems. These feedback loops, time lags, and indirect impacts, resulting from decisions made on a local and larger scale, can have ripple effects, impacting regions throughout the world. Hopefully, coupled research combining social, ecological, 
economic and cultural issues will be the norm in the future.

All attempts were made to ensure the accuracy and consistency of data collection and analysis, however, it is recognized that certain errors may exist. This may stem from the fact that only $0.1 \%$ of the total designated coffee lands were studied with transects, and more extensive research should occur to completely understand the connections between land-use decisions and landscape biodiversity. Additionally, not all plant vouchers were identifiable to the family, genus or species levels and not all plants had known local names, also excluding them from having an identifiable taxonomic nomenclature. These two issues leave room for error in calculating diversity indexes as well as correlations among the different plot types. However, their proper identification could possibly add to the richness of the diversity, not detract from it.

It became apparent during social interviews that many community members did not trust outside researchers, particularly when answering financial and medical questions. Responses to financial questions differed between those given by individuals and community leaders. It was suggested that households were worried that information from this thesis may be used by government agencies to reduce the subsidies that they received, despite being assured that it wouldn't. This made it difficult to accurately analyze and discuss the economic situation currently occurring in the community.

Other discrepancies arise in the evaluation of emigration from households and remittances. Community leaders have stated and published in a community document (ERA A.C., 2000) that $25 \%$ of the population emigrated because of the coffee crisis in the 1990's. Survey responses revealed that only 12 family members had emigrated for that reason. This may be an issue of forgetting or inaccurately recalling events because of 
a long time lapse or unwillingness to share details about family members. As a first time visitor to Santa Cruz Tepetotutla, I cannot expect to have complete trust from all of the community members, and I hope that in the future, more long term studies will take place that aid them in succeeding with their goals of conservation, sustainability and long, happy, healthy lives.

\section{LIST OF REFERENCES}


Aguilar, O.A. 2007. La Chinantla, esquina pródiga de la biodiversidad Mexicana. http://www.mexicoforestal.gob.mx/. Accessed 1/12/11.

Alfaro-Sanchez, G. and Briones-Salas, M. 2004. Suelos. In A.J. García-Mendoza, M.J. Ordóñez Díaz, and M. Briones-Salas, editors. Biodiversidad de Oaxaca. UNAM, Instituto de Biología, Mexico. Pages 55-67.

Alvarez, R. 1994. Geografía general del Estado de Oaxaca. Carteles. $2^{\text {nd }}$ edition. 437446.

Arteaga, A.G. and Calderón, G. 2008. Soil altitudinal sequence on base-poor parent material in a montane cloud forest in Sierra Juárez, Oaxaca. Geoderma. 144:593-612.

Bandeira, F.P., Martorell, C., Meave, J.A. and Caballero, J. 2005. The role of rustic coffee plantations in the conservation of wild tree diversity in the Chinantec region of Mexico. Biodiversity and Conservation. 14:1225-1240.

Berkes, F., J. Colding, and C. Folke. 2000. Rediscovery of traditional ecological knowledge as adaptive management. Ecological Applications. 10:1251-1262.

Bernard, R. 2006. Research Methods in Anthropology: qualitative and quantitative approaches. $4^{\text {th }}$ edition. Alta Mira Press.

Bevan, B. 1938. The Chinantec and their Habitat. Instituto Panamericano de Geografia e Historia. Mexico D.F., Mexico.

Brandon, K. 2002. Putting the right parks in the right places. In J.Terborgh, C. van Schaik, L. Davenport, and M. Rao, editors. Making Parks Work: Strategies for Preserving Tropical Nature. Island Press. Washington, DC. 443-467.

Brash, AR. 1987. The history of avian extinction and forest conversion on Puerto Rico. Biological Conservation. 39:97-111.

Bray, D.B. 1999. Coffee That Eases the Conscience. New York Times op-ed. July 5, 1999.

Bray, D.B., Merino-Perez, L., Negreros-Castillo, P., Segura-Warnholtz, G., Torres-Rojo, J.M. and Vester, H.F.M. 2003. Mexico's community-managed forests as a global model for sustainable landscapes. Conservation Biology. 17:672-677.

Bray, D.B., Merino Perez, L. and Barry, D. 2005. The Community Forests of Mexico: Managing for Sustainable Landscapes. University of Texas Press, Austin, USA.

Bray, D.B., Antinori, C. and Torres-Rojo, J.M. 2006. The Mexican model of community 
forest management: the role of agrarian policy, forest policy and entrepreneurial organization. Forest Policy and Economics. 8:470-484.

Bray, D.B., Duran, E., Anta, S., Martin, G.J. and Mondragon, F. 2008. A new conservation and development frontier: community protected areas in Oaxaca, Mexico. Current Conservation. 2:7-9.

Calo, M. and Wise, T. 2005. Revaluing Peasant Coffee Production: Organic and Fair Trade Markets in Mexico. Global Development and Environment Institute. Tufts University.

Castillo, R. and Acosta, S. 2002. Ethnobotanical Notes on Pinus strobus var. chiapensis. Anales del Instituto de Biología. Serie Botánica. Julio-Diciembre 73. No. 002.

Universidad Nacional Autónomia de México. México D.F. 319-327.

Celis, F. 1993. Desastre agrícola y coroprativismo en la cafeti-cultura. La Jornada del Campo. September, 28.

CEPCO. 2011. The State Coordinator of Coffee Producers of Oaxaca. Accessed 1/12/11.

CONABIO. 2011. Comisión Nacional para el Conocimiento y Uso de la Biodiversidad. Accessed 1/12/11.

Dent, D.H. and Joseph Wright, S. 2009. The future of tropical species in secondary forests: A quantitative review. Biological Conservation. 142:2833-2843.

ERA. A.C. 2000. Estudios Rurales y Asesoria Campesina, A.C. 2000. Estudio para la elaboracion de un plan de uso del suelo en la comunidad de Santa Cruz Tepetotutla. (Internal Document).

FAO. 2003. Food and Agriculture Organization of the United Nations. Medium-term prospects for agricultural commodities. Projections to the year 2010.

FAO. 2010. Food and Agriculture Organization of the United Nations. Accessed 1/12/11.

Figel, J. 2008. Community Protected Areas and the Conservation of Jaguar (Panthera onca) and their Prey in the Chinantla Region of the Sierra Norte, Oaxaca, Mexico. Unpublished Master's Thesis, Florida International University. Department of Environmental Studies.

Galicia, L., Zarco-Arista, A., Mendoza-Robles, K., Palacio-Prieto, J. and García-Romero. 2008. Land use/cover, landforms and fragmentation patterns in a tropical dry forest in the southern Pacific region of Mexico. Singapore Journal of Tropical Geography. 29:137154.

Garcia-Mendoza, A., Ordóñez, M. and Briones-Salas, M. 2004. Biodiversidad de Oaxaca. 
Instituto de Biología, UNAM. Fondo Oaxaqueño para la Conservación de la Naturaleza. World Wildlife Fund. Mexico. 605.

Gentry, A. 1982. Neotropical Floristic Diversity: Phytogeographical Connections Between Central and South America, Pleistocene Climatic Fluctuations, or an Accident of the Andean Orogeny? Missouri Botanical Garden Press.

Gómez-Mendoza, L., Vega-Pena, E., Ramierz, M.I., Palacio-Prieto, J.L., Galicia, L. 2006. Projecting Land-use change processes in the Sierra Norte of Oaxaca, Mexico. Applied Geography. 26:276-290.

Griffith, D.M. 2000. Agroforestry: a refuge for tropical biodiversity after fire. Conservation Biology. 14:325-326.

Hecht, S., Kandel, S., Rosa, H. 2002. Globalization, forest resurgence and environmental politics in El Salvador. San Salvador, PRISMA.

Jaffee, Daniel. 2007. Brewing Justice: Fair Trade Coffee, Sustainability and Survival. University of California Press. Chapter 3. One Region, Two Markets.

Koleff, P., Soberon, J. and Smith, A. 2004. Madrean pine-oak woodlands. In R.A. Mittermeier, P. Robles Gil, M. Hoffmann, J. Pilgrim, T. Brooks, C.G.Mittermeier, J. Lamoreux, and G.A.B. da Fonseca, editors. Hotspots Revisited. CEMEX. 204-217.

Lewis, J. and Runsten, D. 2005. Does Fair Trade Coffee Have a Future in Mexico? The Impact of Migration in a Oaxacan Community. Paper presented at "Trading Morsels" Conference, Princeton University, 2/25. Second Draft. 3/21/05.

Liu, J. et al. 2007. Complexity of Coupled Human and Natural Systems. Science. 317:1513.

Llorente-Bousquets, J., A. L. Martinez, I. Vargas-Fernandez, and J. So-ber6n-Mainero. 1996. Papilionoidea (Lepidoptera). In J. LLorente-Bousquets, A. Garcia-Aldrete, and E. Gonzalez-Sori-ano, editors. Biodiversidad, taxonomia y biogeografia de artr6po-dos de Mexico. Universidad Nacional Aut6noma de Mexico, D.F. 531-548.

Llorente-Bousquets, J. and Ocegueda, S. 2008. Estado del conocimiento de la biota, en Capital natural de México: Conocimiento actual de la biodiversidad. CONABIO, México. 1:283-322.

MacNeish, R.S. 1967. A summary of subsistence. In D. S. Byers, editor. The prehistory of the Tehuacan Valley. University of Texas Press, Austin, TX. 290-309.

Marcano-Vega, H., Aide, T. and Báez, D. 2002. Forest regeneration in abandoned coffee 
plantations and pastures in the Cordillera Central of Puerto Rico. Plant Ecology. 161:7587.

Martin, G.J. 1996. Comparative Ethnobotany of the Chinantec and Mixe of the Sierra Norte, Oaxaca, Mexico. PhD thesis, University of California, Berkeley. 960.

Meave del Castillo, J. 1998. Estudio de la diversidad florística en la región de la Chinantla, Sierra Norte de Oaxaca. Universidad Nacional Autónomia de México. Informe final SNIB-CONABIO proyecto No. P069. México D.F.

Meave, J. A., A. Rincón, and M. A. Romero-Romero. 2006. Oak Forests of the HyperHumid Region of La Chinantla, Northern Oaxaca Range, Mexico. In M.

Kappelle, editor. Ecology and Conservation of Neotropical montane Oak Forests. Springer, Berlin. 113-125.

Merino Pérez, L. and Segura-Warnholtz, G. 2005. Forest and conservation policies and their impact on forest communities in Mexico, in: D. Barton Bray, L. Merino Pérez and D. Barry (Eds), The Community Forests of Mexico: Managing for Sustainable Landscapes, University of Texas Press. 390.

Mitchell, Ross. 2006. Environmental Governance in Mexico: Two Case Studies of Oaxaca's Community Forest Sector. Journal of Latin American Studies. 38:519-548.

Moguel, P. and Toledo, V.M. 1999. Biodiversity Conservation in Traditional Coffee Systems of Mexico. Conservation Biology. 13(1): 11-21.

Molino, J. F. 1986. Agroforests Cafeieres du municipio de Cosautlan (Etat de Veracruz, Mexique). Programme LIDER, Institute Agronomique Mediterraneen, Montpellier, France.

Mongabay. 2011. International Coffee Prices. Historical Statistics. Accessed 2/12/11.

Muñoz, C., Guevara, A., Bulas, J., Torres, J. and Braña, J. 2004. Paying for the Hydrological Services of Mexico's Forests. Center for International Forestry Research. Report 2004.

Murray, D., Raynolds, L. and Taylor, P. 2003. One Cup at a Time: Poverty Alleviation and Fair Trade Coffee in Latin America. Fair Trade Research Group. Colorado State University. Department of Sociology.

Mutersbaugh, T. 1994. Building Cooperatives, Constructing Communality: TimeGeographies of Labor Mobilization in Co-op, Household and Village Commune in Oaxaca, Mexico. Unpublished PhD Dissertation. University of California Berkeley.

Mutersbaugh, T. 2002. Migration, common property and communal labour: cultural 
politics and agency in a Mexican village. Political Geography. 21:473-494.

Nieratka, L. 2011. Do Payments for Hydrological Services Reduce Poverty and Strengthen Social Capital? An Examination of Household Welfare and Collective Action in the Sierra Norte of Oaxaca, Mexico. Unpublished Master's Thesis. Florida International University.

Nestel, D. 1995. Coffee and Mexico: International market, agricultural landscape, and ecology. Ecological Economics. 15:165-179.

Nir, M.A. 1988. The survivors: Orchids on a Puerto Rican coffee finca. American Orchid Society Bulletin. 57:989-99.

Ortiz-Perez, M. A., J. Hernandez-Santana, and J. Figueroa Mah-Eng. 2004. Reconocimiento fisiografico y geomorfologico. In A. J. García-Mendoza, M. d. J. Ordóñez Díaz, and M. Briones-Salas, editors. Biodiversidad de Oaxaca. UNAM, Instituto de Biología, Mexico. 43-54.

Ostrom, E. 1990. Governing the Commons. The Evolution of Institutions for Collective Action. Chapter 3. Analyzing long-enduring, self-organized, and self-governed CPRs. Cambridge University Press.

Pascarella, J., Aide, T., Serrano, M. and Zimmerman, J. 2000. Land-Use History and Forest Regeneration in the Cayey Mountains, Puerto Rico. Ecosystems. 3:217-228.

Pérez-Grovas, V., Cervantes, E. and Burstein, J. 2001. Case Study of the Coffee Sector in Mexico.

Perfecto, I. and Armbrecht, I. 2003. The coffee agroecosystem in the Neotropics: Combining ecological and economic goals. In: Vandermeer J (ed). Tropical Agroecosystems. CRC Press. Boca Raton. 159-194.

Perfecto, I., Armbrecht, I., Philpott, S.M., Soto-Pinto, L. and Dietsch, T.V. 2007. Shaded coffee and the stability of rainforest margins in northern Latin America. In Tscharntke, T., Leuschner, C., Zeller, M., Guhardja, E. and Bidin, A. (eds). The stability of tropical rainforest margins, linking ecological, economic and social constraints of land use and conservation. Springer Verlag Berlin. 227-263.

Philpott, S., Arendt, W., Armbrecht, I., Bichier, P., Diestch, T., Gordon, C., Greenberg, R., Perfecto, I., Reynoso-Santos, R., Soto-Pinto, L., Tejeda-Cruz, C., Williams-Liner, G., Valenzuela, J. and Zolotoff, J. 2008. Biodiversity Loss in Latin American Coffee Landscapes: Review of the Evidence on Ants, Birds, and Trees. Conservation Biology. 22(5):1093-1105.

Poleman,T. 1964. The Papaloapan Project. Standford University Press, Standford, CA. 
Rendon, A., and B. N. Turrubiarte. 1985. El cultivo del cafe: caracterizaci6n del manejo y estructurade cuatro huertos en el ejido "El Quemado," Municipio de Atoyac de Alvarez, Guerrero. Tesis de Lic. en Biologia Facultad de Ciencias, Universidad Nacional Aut6noma de Mexico, Mexico, D.F.

Rice, R. 1997. The land use patterns and the history of coffee in eastern Chiapas, Mexico. Agriculture and Human Values. 14:127-143.

Rice, R. and Ward, J. 1996. Coffee, Conservation, and Commerce in the Western Hemisphere. How Individuals and Institutions Can Promote Ecologically Sound Farming and Forest Management in Northern Latin America. Natural Resources Defense Council and the Smithsonian Migratory Bird Center. White Papers.

Rice, P. and McLean, H. 1999. Sustainable Coffee at the Crossroad. White Paper prepared for The Consumer's Choice Council. October 5, 1999.

Rivera, LW, and TM Aide. 1998. Forest recovery in the karst region of Puerto Rico. Forest Ecology and Management. 108:63-75.

Robson, J.P. 2009. Local approaches to biodiversity conservation: lessons from Oaxaca, southern Mexico. International Journal of Sustainable Development. 0.0.

Rouvinen, S. and Kuuluvainen, T. 2005. Tree diameter distributions in natural and managed old Pinus sylvestris dominated forests. Forest Ecology and Management. 208:45-61.

Santoyo Cortés, Horacio, S. Díaz Cárdenas y B. Rodríguez P. 1995. Sistema agroindustrial café en México. Universidad Autónoma Chapingo. México. 176.

Schultes, R.E. 1941. The meaning and usage of the Mexican place-name "Chinantla." Botanical Museum Leaflets, Harvard University. 9:101-116.

Southgate et al. 2009. Payments for environmental services and rural livelihood strategies in Ecuador and Guatemala. Environment and Development Economics. 15:2137

Toledo, V.M., Batis, A., Becerra, R., Martínez, E. and Ramos, C.H. 1995. La selva útil: etnobotánica cuantitativa de los grupos indigenas del trópico húmedo de México. Interciencia. 20:177-187.

Toledo, V. M., B. Ortiz-Espejel, L. Cortés, P. Moguel, and M. D. J. Ordoñez. 2003. The multiple use of tropical forests by indigenous peoples in Mexico: a case of adaptive management. Conservation Ecology. 7(3):9.

Topik, S., Talbot, J. and Samper, M. 2010. Introduction Globalization, Neoliberalism, 
and the Latin American Coffee Societies. Latin American Perspectives. 37:5.

Tscharntke T., Sekercioglu, C., Dietsch, T., Sodhi, N., Hoehn, P. and Tylianakis, J. 2008. Landscape Constraints on Functional Diversity of Birds and Insects in Tropical Agroecosystems. Ecology. 89(4):944-951.

Tucker, C., Eakin, H. and Castellanos, E. 2010. Perceptions of risk and adaptation: Coffee producers, market shocks, and extreme weather in Central America and Mexico. Global Environmental Change. 20:23-32.

Van der Wal, H. 1999. Chinantec Shifting Cultivation: Interactive Land Use. A Case Study in the Chinantla, México, on Secondary Vegetation, Soils and Crop Performance under Indigenous Shifting Cultivation. Treemail Publishers, Treebook 3. Heelsum, The Netherlands.

VanWey, L., Tucker, C. and McConnell, E. 2005. Community Organization, Migration, and Remittances in Oaxaca. Latin American Research Review. 40(1):83.

Weaver, PL, and RA Birdsey. 1986. Tree succession and management opportunities in coffee shade stands. Turrialba. 36:47-58.

WWF. 2005. World Wildlife Foundation. Conservation Science: Global 200 Ecoregions. Accessed 10.12.10.

Zimmerman, J., Aide,T., Rosario,M., Serrano, M. and Herrera, L. 1995. Effects of land management and a recent hurricane on forest structure and composition in the Luquillo Experimental Forest, Puerto Rico. Forest Ecology and Management . 77:65-76. 


\section{APPENDIX 1: TRANSECT DATA SHEETS}

Area \# Trail \#

Plot \#

Date

Field worker

Guide

Location

Owner

Plot Activities

Size of plot

ha

Altitude

m Slope degree

Slope orientation

Coordinates $\mathrm{N}$ W GPS \#

\begin{tabular}{|l|l|l|l|l|}
\hline $\mathrm{Nu}$ & Local plant name & DBH & Collected & Notes/Observations \\
\hline 1 & & & & \\
\hline 2 & & & & \\
\hline 3 & & & & \\
\hline 4 & & & & \\
\hline 5 & & & & \\
\hline 6 & & & & \\
\hline 7 & & & & \\
\hline 8 & & & & \\
\hline 9 & & & & \\
\hline 10 & & & & \\
\hline 11 & & & & \\
\hline 12 & & & & \\
\hline 13 & & & & \\
\hline 14 & & & & \\
\hline 15 & & & & \\
\hline 16 & & & & \\
\hline 17 & & & & \\
\hline 18 & & & & \\
\hline 19 & & & & \\
\hline 20 & & & & \\
\hline
\end{tabular}




\begin{tabular}{|l|l|l|l|l|}
\hline Shade/Cover & North & East & South & West \\
\hline 0 meters & & & & \\
\hline 25 meters & & & & \\
\hline 50 meters & & & & \\
\hline
\end{tabular}

Observations: 


\section{APPENDIX 2: HOUSEHOLD SURVEY}

\section{Payments for Hydrological Services and the Abandonment of Coffee}

\begin{tabular}{|c|c|}
\hline \multicolumn{2}{|c|}{ Name of Interviewer } \\
\hline Lindsey & 1 \\
\hline Ernesto & 2 \\
\hline Emily & 3 \\
\hline
\end{tabular}

child.

\section{Date of the Survey}

\section{Guide:}

Protocol: 1) make appointments in the houses 2)ask for the head of the house 3) if the head of the house is not home, do the interview with the spouse or elder

Introduction:

Good afternoon. My name is I am part of a research team of CIIDIR-Oaxaca and Florida International University in the United States. We are working with Elvira Duran and David Bray. We are looking at the emigration of the community, coffee, and payments for watershed services received by the community. This should take one hour of your time. We have the commissioner's permission to do research in the community. All data and information that you give me during the survey will serve as part of my study only and are completely confidential. If you decide to participate in the study he makes a series of questions hoping that their answers are as complete as possible because the data that we collect could serve the community. May I continue?

Community :

(SCT - Santa Cruz Tepetotutla; SPT - San Pedro Tlatepusco)

Section 1 -Demography of the House

1.1 Head of Household

1.2 Name

1.3 Gender $\mathrm{M}$

1.4 Age

1.5 civil state

\begin{tabular}{|l|l|}
\hline \multicolumn{2}{|c|}{1.6 What positions have you held in } \\
the comisariado?
\end{tabular}

Home Information:

1.7 Type of floor: $\operatorname{dirt}$ cement clay tile other (Which?

1.8 Principal material of walls: brick wood

1.9 Material of the roof: sticks and leaves leaves tile adobe

1.10 How many rooms in the house?

1.11 What type of bathroom?: flushing toilet rustic latrine dry latrine

none 
Box 1.12 1.12 Now I will ask you questions about the people who actually live in the house First, can you tell me how many people live in the house?

\begin{tabular}{|c|c|c|c|c|c|c|}
\hline No. & a) Name & 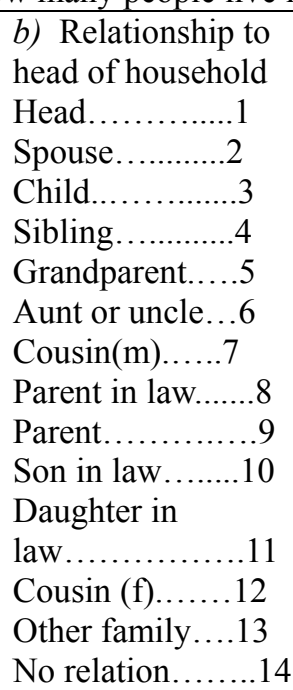 & c) Age & $\begin{array}{l}d \text { ) Education } \\
\text { level } \\
\text { Preschool . .1 } \\
\text { Primary } 1-.3 \ldots . . .2 \\
\text { Primary } 4-6 \ldots . . .3 \\
\text { Secondary...4 } \\
\text { Prep ........5 } \\
\text { Undergraduate..6 } \\
\text { Did not attend..7 } \\
\text { Other......8 } \\
\text { Which? }\end{array}$ & $\begin{array}{l}\text { e) Did you } \\
\text { immigrate } \\
\text { to the US? } \\
\text { Yes/No }\end{array}$ & $\begin{array}{l}\text { f) Do you } \\
\text { contribute } \\
\text { money to } \\
\text { the } \\
\text { household? } \\
\text { Yes or No }\end{array}$ \\
\hline 1 & & 1 & & & & \\
\hline 2 & & 2 & & & & \\
\hline 3 & & & & & & \\
\hline 4 & & & & & & \\
\hline 5 & & & & & & \\
\hline 6 & & & & & & \\
\hline 7 & & & & & & \\
\hline 8 & & & & & & \\
\hline 9 & & & & & & \\
\hline 10 & & & & & & \\
\hline
\end{tabular}

1.13 How many children do you have in total?

$1.13 a$ of those, how many live in the house?

$1.13 \mathrm{~b}$ How many live in the community?

$1.13 \mathrm{c}$ How many live outside the community?

1.13f How many have died?

Section 2 - People who contribute money to the house

Now I would like to ask a few questions about the income that comes into the house.

2.1 Do you receive money sent by someone who is outside of the house?

Yes No 
Box 2.2 Family members who send money.

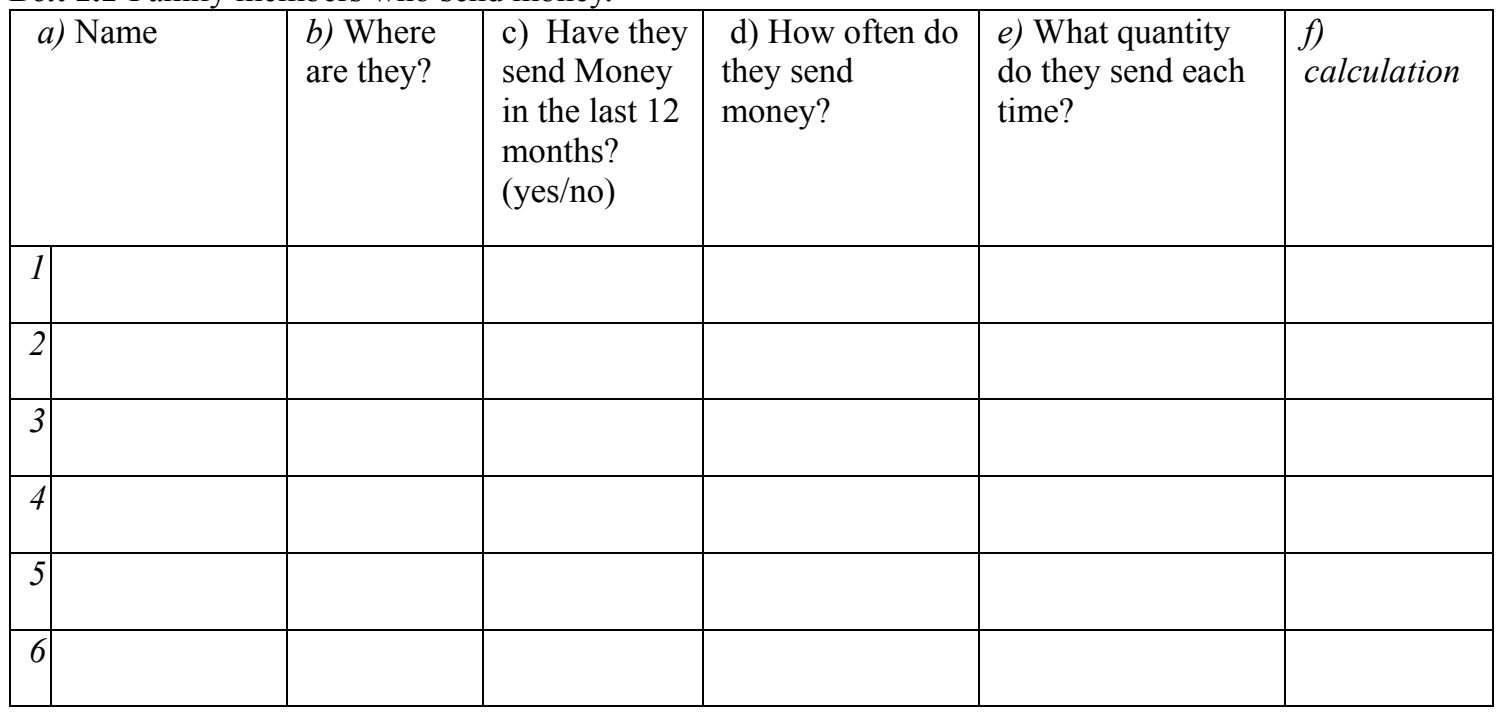

Agricultural Activities. Now I will ask about your agricultural activities.

\section{Café}

2.3 How many hectares of coffee do the members of the household have?

In how many parcels?

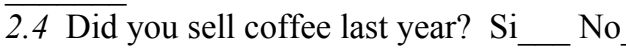

2.5 What was your total production in kilos last year? kilos

\begin{tabular}{|l|l|l|l|l|}
\hline 2.5a Who did you sell to? & $\begin{array}{l}\text { b) How many } \\
\text { kilos? }\end{array}$ & $\begin{array}{l}c \text { ) What did } \\
\text { they pay for } \\
\text { the kilo? }\end{array}$ & $\begin{array}{l}d \text { ) How much did } \\
\text { they pay in total? }\end{array}$ & $\begin{array}{l}\boldsymbol{e} \text { ) Kilos } \mathbf{x} \\
\text { Price }=\end{array}$ \\
\hline 1) Coffee Cooperative & & & & \\
\hline 2) Coyote $\quad$ Other: & & & & \\
\hline 3$) \quad$ & & & \\
\hline
\end{tabular}

Box 2.6: Active coffee

\begin{tabular}{|c|c|c|c|c|c|c|c|}
\hline Plot & $\begin{array}{l}\text { a) } \\
\text { Where } \\
\text { is it? }\end{array}$ & $\begin{array}{l}\text { b) How many } \\
\text { times do you } \\
\text { clean it per } \\
\text { year? } \\
1 \text { time........1 } \\
2 \text { times....2 }\end{array}$ & $\begin{array}{l}\text { c) What type of } \\
\text { coffee? } \\
\text { Organic....1 } \\
\text { Convencional...2 }\end{array}$ & $\begin{array}{l}\text { d) Are } \\
\text { there } \\
\text { other } \\
\text { plants } \\
\text { used? }\end{array}$ & $\begin{array}{l}\text { e) Which } \\
\text { plants? } \\
\text { Fruit..........1 } \\
\text { Corn.........2 } \\
\text { Beans.........3 } \\
\text { Other......... }\end{array}$ & $\begin{array}{l}\text { f) Have you } \\
\text { cut it? } \\
\text { Yes.....1 } \\
\text { No.....2 }\end{array}$ & $\begin{array}{l}\text { g) If yes } \\
\text { (f), when? }\end{array}$ \\
\hline 1 & & & & & & & \\
\hline 2 & & & & & & & \\
\hline 3 & & & & & & & \\
\hline 4 & & & & & & & \\
\hline
\end{tabular}


Box 2.7: Inactive Coffee Plots

\begin{tabular}{|c|c|c|c|c|c|c|c|c|}
\hline Plot & $\begin{array}{l}\text { a) } \\
\text { Where } \\
\text { is it? }\end{array}$ & $\begin{array}{l}\text { b) Plot } \\
\text { activities } \\
\text { Abandoned.1 } \\
\text { Convert to } \\
\text { polyculture.2 } \\
\text { Annual agr..3 } \\
\text { Other..........4 }\end{array}$ & $\begin{array}{l}\text { c)When } \\
\text { was it } \\
\text { abandoned? }\end{array}$ & $\begin{array}{l}\text { d) Other } \\
\text { plot } \\
\text { activities } \\
\\
\text { Wood....1 } \\
\text { Livestock.. } \\
2 \\
\text { Other. . } 3\end{array}$ & $\begin{array}{l}\text { e) Annual } \\
\text { Agr. } \\
\text { Corn..1 } \\
\text { Yucca..2 } \\
\text { Other...3 }\end{array}$ & $\begin{array}{l}\text { f) Why was } \\
\text { it } \\
\text { abandoned? } \\
\text { Price.. } 1 \\
\text { Emigration. } 2 \\
\text { Infestation. } 3 \\
\text { Otro......4 }\end{array}$ & $\begin{array}{l}\text { g) When } \\
\text { abandoned } \\
\text {, did } \\
\text { someone } \\
\text { have to } \\
\text { emigrate? } \\
\text { Yes...1 } \\
\text { No....2 }\end{array}$ & $\begin{array}{l}\text { h) } \\
\text { Will } \\
\text { you } \\
\text { plant } \\
\text { coffee } \\
\text { again? } \\
\text { Yes...1 } \\
\text { No....2 }\end{array}$ \\
\hline 1 & & & & & & & & \\
\hline 2 & & & & & & & & \\
\hline 3 & & & & & & & & \\
\hline 4 & & & & & & & & \\
\hline 5 & & & & & & & & \\
\hline 6 & & & & & & & & \\
\hline
\end{tabular}

2.8 Before coffee, what was in the plot?

2.9 When did you first plant coffee?

2.10 Did you plant shade trees? Yes __ No ___ 2.10a What kinds of shade trees?

$2.10 \mathrm{~b}$ What percent of shade did your plots initially have?

2.11 How many hectares of corn do the people in the house have?

2.12 How many kilos did you harvest last year?

2.13 Did you lose an area of corn because of the community agreements? Yes No

2.13a Where was it? 2.13b How many hectares?

$2.13 \mathrm{c}$ What year did you lose it?

$2.13 \mathrm{~d}$ Did you find another place to plant corn? Yes No

Other products that you sold

2.14 Other than coffee, do you have other products that you cultivate or collect that you also sell? Yes No

\begin{tabular}{|c|c|c|c|c|}
\hline \multirow[t]{2}{*}{$\begin{array}{l}2.14 \text { a) Product/crop } \\
\text { (Guasmol, tepejilote, } \\
\text { naranja, plátano ect. . . .) }\end{array}$} & \multicolumn{2}{|c|}{$\begin{array}{l}\text { b) How much did you } \\
\text { sell in the last } 12 \\
\text { months? }\end{array}$} & \multirow[t]{2}{*}{$\begin{array}{l}\text { c) What price did you } \\
\text { receive per unit? }\end{array}$} & \multirow[t]{2}{*}{ d) Calculation } \\
\hline & Quantity & $\begin{array}{l}\text { Unit of } \\
\text { measure }\end{array}$ & & \\
\hline \multicolumn{5}{|l|}{ 1) } \\
\hline \multicolumn{5}{|l|}{ 2) } \\
\hline 3) & & & & \\
\hline
\end{tabular}




\section{Cattle and yard animals}

2.15 Do you have any cattle? Yes ___ No

$2.15 a$ Did you sell any cattle in the last year? Yes No

2.15b Did you sell any other animal last year? Yes No

\begin{tabular}{|c|l|l|l|l|}
\hline \multicolumn{2}{|l|}{$2.15 c$ What? } & d) How many? & e) What price? & $\begin{array}{l}\text { f) \$ for the } \\
\text { year }\end{array}$ \\
\hline 1 & & & & \\
\hline 2 & & & & \\
\hline 3 & & & & \\
\hline
\end{tabular}

Work in other parcels

Box 2.16 Do you or anyone in the house work as a day laborer? Yes _ No

\begin{tabular}{|c|l|l|l|l|l|}
\hline \multicolumn{2}{|c|}{ a) Name } & $\begin{array}{l}\text { b) How much do } \\
\text { you earn per day? }\end{array}$ & $\begin{array}{l}\text { c) How many } \\
\text { days did you } \\
\text { work in corn? }\end{array}$ & $\begin{array}{l}\text { d) How many } \\
\text { days did you } \\
\text { work in coffee? }\end{array}$ & e) \$ for the year \\
\hline 1 & & & & & \\
\hline 3 & & & & & \\
\hline 4 & & & & & \\
\hline
\end{tabular}

Other Sources of Income Now I would like to ask about other sources of income 2.17 Does anyone in the house have another source of income? Yes No

\begin{tabular}{|l|l|l|l|}
\hline a) Name & b) Type of work & $\begin{array}{c}\text { c) How much do you } \\
\text { earn per } \\
\text { day/week/month? }\end{array}$ & d) \$ for the year \\
\hline 1$)$ & & & \\
\hline 2) & & & \\
\hline 3$)$ & & & \\
\hline & & & \\
\hline
\end{tabular}

7.

Other source of income?

Yes No 


\section{SECTION 3 - Sources of Income from Government Programs}

3.1 Do you receive assistance from PROCAMPO? Yes

No

$$
\text { 3.1 a How many hectares? }
$$

$(\mathrm{X} 1300=$

3.2 Do you receive assistance from OPPORTUNIDADES? Yes No $3.2 a$ How many children receive?

Can you tell me their names?

\begin{tabular}{|c|c|c|c|c|c|}
\hline $\begin{array}{l}\text { No } \\
\text {. }\end{array}$ & b) name of child & $\begin{array}{l}\text { c) Gender } \\
\text { Male............1 } \\
\text { Female..........2 }\end{array}$ & d) grade level & $\begin{array}{l}\text { e) amount } \\
\text { received }\end{array}$ & $\begin{array}{l}\text { f) amount } \\
\text { for the year }\end{array}$ \\
\hline 1 & & & & & \\
\hline 2 & & & & & \\
\hline 3 & & & & & \\
\hline 4 & & & & & \\
\hline 5 & & & & & \\
\hline
\end{tabular}

3.3 Does anyone in the house receive "SETENTA O MAS"? Yes No

\begin{tabular}{|l|l|l|}
\hline $\mathrm{N}$ & $3.3 a$ Who? & $3.3 b$ how much? \\
\hline $\mathrm{o}$. & & \\
\hline 1 & & \\
\hline 2 & & \\
\hline
\end{tabular}

3.4 Does anyone receive aid from temporary employment? (PET)? Yes_ No

\begin{tabular}{|c|l|l|l|}
\hline $\mathrm{N}$ & $3.4 a$ Who? & $3.4 b$ How often? & $\begin{array}{l}3.4 c \text { How much do they receive } \\
\text { every time? }\end{array}$ \\
\hline 1 & & & \\
\hline 2 & & & \\
\hline 3 & & & \\
\hline
\end{tabular}

\section{SECCION 4 - Non monetary aid}

4.1 Have you received a greenhouse? Yes No 4.1a Is it functioning now? $\mathrm{Si}$ No

4.2. Have you received an aquiculture project? $\mathrm{Si}$ No 4.2a Is it functioning now? $\mathrm{Si}$ No

Are there any other programs that have benefited you? yes No 4.3a What are they?

\begin{tabular}{|c|l|l|}
\hline \multicolumn{2}{|l|}{$4.3 \mathrm{~b}$ Organization } & $4.3 \mathrm{c}$ Program \\
\hline 1 & & \\
\hline 2 & & \\
\hline 3 & & \\
\hline
\end{tabular}




\section{Section 5 - PSA-H}

Now I am going to ask you about the payments for hydrological services.

5.1 Do you know why the community is receiving payments for hydrological services?

5.1 a Why?

Yes

5.2 How many people in the house have money deposited in the bank from the PES? $\mathrm{SCT} / \mathrm{X} \_$_

5.3 When they distributed the entire fund from the bank, how much did you receive? (SCT)

$5.5 \mathrm{a}$ What is the most important thing you bought with the money?

$5.5 \mathrm{~b}$. What is the second most important thing you did with the money?

5.4 How many people received a direct distribution of the money last year?

$(\mathrm{X} 500=$

$\mathrm{SCT} / \mathrm{X}$ $=$ SPT)

5.5 Is there an elder in the house who receives the payment? $\mathrm{Si}$

No

$(\mathrm{X} 200 / \mathrm{mes}=$ $\mathrm{SCT} /$

5.6 How have you used your money that is kept in the bank?

\begin{tabular}{|l|l|l|l|}
\hline \multicolumn{2}{|l|}{ Use } & $\begin{array}{l}\text { How many times have you } \\
\text { used the money this way? }\end{array}$ & How much have you used? \\
\hline 1 & Medical costs & & \\
\hline 2 & $\begin{array}{l}\text { Household } \\
\text { improvements }\end{array}$ & & \\
\hline 3 & $\begin{array}{l}\text { Production } \\
\text { activities }\end{array}$ & & \\
\hline 4 & Other & & \\
\hline
\end{tabular}

5.7 Do you know how many hectares are within the PSAH program? yes

No

5.8 a How many?

5.8 What are the restrictions on use of soil within the program?

5.9 Do you believe that the payments are distributed in an equal manner? Yes 5.10 a Why?

No

5.10 Do you think that the payments for hydrological services are worth the restrictions that are placed on the forest for conservation? yes No

5.11 Do you agree with the way that the payments are distributed? $\mathrm{Si}$

No 5.12a Why?

5.12 Has your economic situation improved because of the payments for environmental services? Yes No

\subsection{3a Why?}


5.13 Do you think that the 400 pesos per hectare per year that the government is paying are enough? Yes No

5.13a If no ... what is the least they should pay per hectare per year?

\section{Section 6 - Disposition to accept payments for carbon services**}

Trees are very important not only for water supply, but also for the climate control by reducing carbon, $a$ pollutant that is causing climate change. In many parts of the world, governments and companies are paying landowners to plant trees or for conservation. In this way buyers will earn about carbon credits to sell on the market.

6.1 - Would you be interested in participating in a program in which you would be paid to either plant trees or continue conserving the forests with the end of removing carbon from the air?

Yes No

Every other survey explain that the market price is more or less 200 pesos per hectare per year. Explain that by asking for less means losing but to ask much more means that people can look elsewhere in the project. __ explain__ Do not explain

6.2 -Now, the community earns 400 pesos per hectare per year for the hydrological services. With this money the community pays for the costs of the comisariado, the activities of natural resource conservation and you receive a payment. You have more than nine thousand acres under conservation but only four thousand are in the program of payments for environmental services. Then there is no payment for 5000 hectares. What should the community accept per hectare per year in payments for the capture of carbon inside the 5,000 hectares that do not have a payment within the area of conservation?

6.3 What is the least the community will accept in carbon payments for conservation?

6.4 In many cases, payments for carbon require that the recipients plant trees where there are none. What will the community accept per hectare per year to cut down coffee plantations and plant forest trees?

6.5 What is the least the community would accept per hectare per year to cut down coffee plantations and plant forest trees? 